\title{
Evaluation of Land Potential for Use of Biosolids in the Coastal Mediterranean Karst Region
}

\author{
Vito Horvatić ${ }^{1}$, Helena Bakić Begić ${ }^{1}{ }^{(}$, Davor Romić ${ }^{1}$, Marko Černe ${ }^{2}{ }^{\oplus}$, Smiljana Goreta Ban ${ }^{2}(\mathbb{D}$, \\ Monika Zovko ${ }^{1}$ (D) and Marija Romić ${ }^{1, *(\mathbb{D})}$ \\ 1 Department of Soil Amelioration, University of Zagreb Faculty of Agriculture, Svetošimunska 25, \\ 10000 Zagreb, Croatia; vito.zg@hotmail.com (V.H.); hbakic@agr.hr (H.B.B.); dromic@agr.hr (D.R.); \\ mzovko@agr.hr (M.Z.) \\ 2 Institute of Agriculture and Tourism, Karla Huguesa 8, 52440 Poreč, Croatia; marko@iptpo.hr (M.Č.); \\ smilja@iptpo.hr (S.G.B.) \\ * Correspondence: mromic@agr.hr
}

check for updates

Citation: Horvatić, V.; Begić, H.B.; Romić, D.; Černe, M.; Goreta Ban, S.; Zovko, M.; Romić, M. Evaluation of Land Potential for Use of Biosolids in the Coastal Mediterranean Karst Region. Land 2021, 10, 1035. https:// doi.org/10.3390/land10101035

Academic Editor: Saskia Keesstra

Received: 14 September 2021

Accepted: 29 September 2021

Published: 2 October 2021

Publisher's Note: MDPI stays neutral with regard to jurisdictional claims in published maps and institutional affiliations.

Copyright: (c) 2021 by the authors. Licensee MDPI, Basel, Switzerland. This article is an open access article distributed under the terms and conditions of the Creative Commons Attribution (CC BY) license (https:// creativecommons.org/licenses/by/ $4.0 /)$.

\begin{abstract}
The aim of this study was to evaluate the potential of agricultural land in the coastal Adriatic Karst region (Šibenik region, Croatia) for biosolids application by integrating spatial data from different sources: digital maps and remote sensing, parcel identification system, GIS field observations and measurements focusing on specific land and soil properties. Due to the rapid development of the wastewater treatment industry, excessive accumulation of sewage sludge (SS) in wastewater treatment plants is a growing problem worldwide. Management options for land application of biosolids require a comprehensive characterization of both SS and SS-amended soils. The assessment of agricultural land in the study area for SS disposal was based on EU and national legislation. The evaluation revealed that agricultural land in the study area accounts for only $10 \%$ of the total area $(25,736 \mathrm{ha})$, but only a quarter of the existing land (6065 ha) is suitable for biosolids application. Furthermore, the data indicate that the sewage sludge can be safely applied to the soil in terms of soil metals according to the Croatian legislation. The short-term potential of the soil to sustain this ecosystem service, namely soil improvement with biosolids, should be used to determine the inherent long-term potential based on resistance to soil degradation and resilience. However, caution is needed and the long-term effects should be investigated before biosolids are continuously used for soil application.
\end{abstract}

Keywords: ecosystem services; land evaluation tools; spatial information; soil attributes; land degradation; soil heavy metals

\section{Introduction}

In the context of integrated land and water management, the generation of wastewater and the growing quantities of biosolids from local wastewater treatment plants are issues of high importance worldwide [1]. The term biosolids is used to refer to the nutrient-rich organic materials generated during the treatment of domestic wastewater in a wastewater treatment plant during the primary (physical and/or chemical), secondary (biological) and tertiary (in addition to secondary) treatment processes of the wastewater [2]. The terms "biosolids" and "sewage sludge" (SS) are often used interchangeably [3]. Anaerobic digestion and composting are the two most widespread SS stabilization processes at wastewater treatment plants (WWTP), which play a key role in SS recycling and utilization [4].

Operating methods and regulatory framework to ensure the proper application of biosolids for protection of the environment and human health have been defined worldwide and applied at both international and national levels $[3,5,6]$. In the EU, there is a general impression that the Sewage Sludge Directive (SSD) issued in 1986 [7], although it has well fulfilled its objective of ensuring the diverse and safe use of sewage sludge, needs to be revised to meet the new challenges: emerging pollutants, digitalization and the circular 
economy [8]. Current national regulations on this issue differ between EU member states, resulting in a fragmented legal framework in which sewage sludge is still classified as waste and managed in a coherent manner [9]. The differences in the legislation strictness at the national level can be reasonably explained by the different geomorphology, marked climatic differences and variability of soil types within the country. However, few countries have enacted regional legislation to regulate the use of sewage sludge in different areas, such as in Italy [10].

Croatian Adriatic coastline is a region of exceptional karst landscape, and the main drivers of the regional economy are agriculture and tourism. The population density in the region is rather low ( 36.65 inhabitants per square kilometer of land area), but since it is an attractive tourist region, the production of SS in sewage treatment plants is continuously growing [11]. The Šibenik region (Middle Eastern Adriatic) has in the past been confronted with the serious problem of eutrophication of the Krka River Estuary and the coastal marine environment, which has been receiving untreated industrial and domestic wastewater for years [12].

The discharge of SS into the Adriatic Sea was stopped in 2008 after the construction of a wastewater treatment plant, and the treated wastewater is discharged into the nearshore marine environment SE of Zlarin Island through a $5000 \mathrm{~m}$ submarine pipe system [13]. Nowadays, most households, industrial and municipal facilities in the Šibenik region are connected to the WWTPs, and eight plants are currently in full operation. After the installation of the solar SS drying plant, the annual production of biosolids that should be managed is estimated at two thousand tons of dry matter per year.

However, the end-use scheme to solve the problem of increasing production of biosolids in the agglomeration has not yet been defined. Currently, the end use of biosolids varies worldwide and is determined by the quality of the product and the available options for beneficial use or disposal [14]. While biosolids can be used as a valuable resource for organic matter, nutrients and trace elements, land application appears to be a preferred management option compared to conventional disposal, which is now limited [15].

For the application of biosolids to land, European Union provides a legal framework at Council Directive (86/278/EEC). However, Hudcová and Vymazal [16] pointed out that this directive, being outdated, does not meet the current requirements for ensuring the safety of SS application in agriculture. Croatia, as an EU member state, has developed national legislation based on this directive [17]. Besides the restriction on the choice of crops, one of the important points in the sewage sludge regulation is the setting of limits for heavy metal concentrations, pathogens and organic compounds, as well as sludge and soil analysis and their frequency.

Biosolids are the most researched and regulated organic material applied to land, and information sources agree on the significant potential of such a practice. Although the current regulation on the reuse of biosolids to agriculture in Croatia is in line with the EU Sludge Directive (86/27/EEC), there are important differences between the various regulations, especially in relation to the permitted uses. In addition, scientific support is needed for the development of national guidelines to complement a future regulation on the application of biosolids, taking into account regional specificities.

Karst environments are considered to be highly fragile environments in the world, extremely vulnerable to a range of degradation events [18]. Moreover, karst aquifers are characterized by rapid recharge via karst features and extensive surface water-groundwater interaction. Due to the carbonate environment and the exposure of bare rock, there is generally no true water flow system at the surface as water rapidly infiltrates into the subsurface through the network of karst fissures and conduits in the rock mass [19]. This fact is crucial for understanding the risk that the application of sewage sludge and the leaching of potentially toxic substances contained in the sludge may have on karst aquifers.

The use of SS as a soil amendment has many benefits when it comes to improving the nutrient status of depleted Mediterranean soils [20,21] and, therefore, the application of SS 
as an organic fertilizer has increased in recent years [22,23]. Restoration of degraded soils with organic waste could also be a viable method to minimize erosion in such areas [24].

Considering the ecosystem service of agricultural land as SS amendment in addition to agricultural production, SS sustainable management and environmental protection, and based on the current legislation defining the conditions for the application of SS on agricultural land, this study was aimed: (i) to provide the methodology of rapid evaluation of agricultural land for biosolids application by integrating different spatial information such as digital maps and remote sensing, parcel identification system, GIS field observations and measurements, and (ii) to assess the potential of agricultural land within the study area for SS use as soil amendment, focusing on specific soil and land properties, including pedo-geochemical characterization of agricultural land.

\section{Materials and Methods}

\subsection{Study Area and Land Resources Inventory}

According to the Croatian regional administrative system, the study area belongs to Šibensko-kninska County, located in Central Dalmatia (Figure 1). The region covers $2984 \mathrm{~km}^{2}$ with a population of 109,375 inhabitants [25]. As a coastal area on the Adriatic Sea, attractive for its exceptional natural resources and cultural heritage, the county is a popular tourist destination and the number of tourists is higher than the number of inhabitants during the summer months.

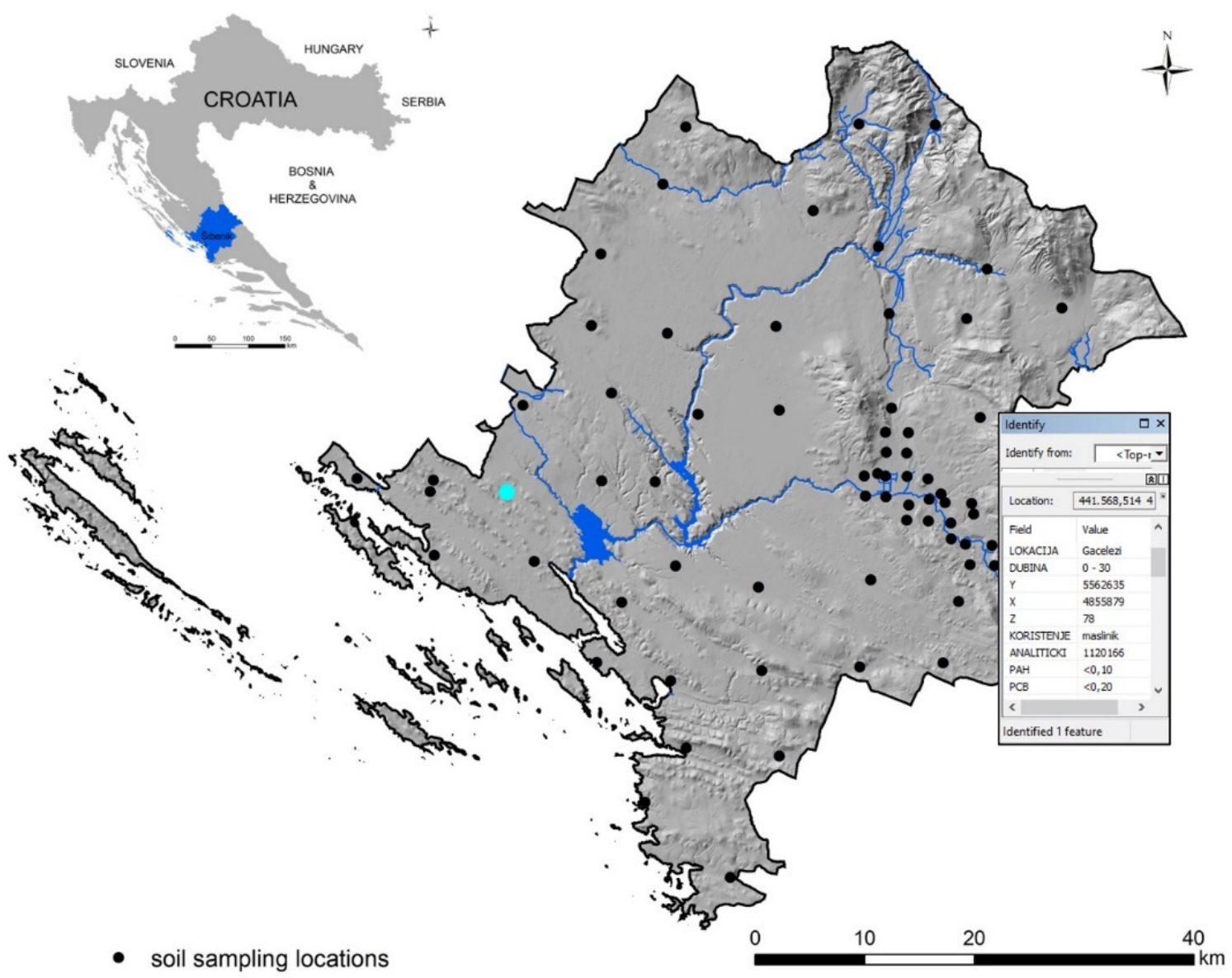

Figure 1. Geographical setting of the study area, surface soil sampling points and GIS sample point identify window (turquoise dot).

Geospatial tools combined with targeted field studies were used for the land resources inventory. Information on spatial distribution and classification of soils and land use was processed. Soil and land use mapping were used to identify different site-specific soil 
management practices and agricultural land was found to occupy about $10 \%$ of the total land area (5736 ha). Different types of agricultural land use were identified using remotely sensed data and land parcels database, particularly Croatian agricultural parcel identification system (ARKOD), which is a national agricultural parcel identification system [26]. The 1:25,000 digital soil map was used to identify dominant soil types in the study area.

Soil survey and sampling were carried out according to the square mesh sampling grid with sampling points spaced at $8 \times 8 \mathrm{~km}$ using 1:25,000 scale topographic maps, apart from the Petrovo polje area where the sampling distance was $1 \mathrm{~km}$ (Figure 1). The composite samples were made up of 10 soil subsamples taken in a cross pattern, with a $5 \mathrm{~m}$ distance between subsamples. The observation sites were spatially referenced using GPS and data were stored in different GIS layers. A site survey, carried out during the sampling process, provided site-specific information related to land use and other human activities near the sampling points.

\subsection{Laboratory Methods}

Soil samples (average weight $2 \mathrm{~kg}$ ) were air-dried, and, after homogenisation, half of each sample was sieved through a $2 \mathrm{~mm}$ mesh screen and stored in polyethylene bottles as a backup sample.

The other half was sieved through a $0.5 \mu \mathrm{m}$ mesh and used for determining soil concentrations of heavy metals after microwave (MARSXpress system, CEM) assisted aqua regia digestion [27]. Elements' concentration $(\mathrm{Cd}, \mathrm{Cr}, \mathrm{Cu}, \mathrm{Ni}, \mathrm{Pb}$ and $\mathrm{Zn})$ in soil digests were determined by inductively coupled plasma optical emission spectroscopy (ICP-OES) (Vista-MPX AX, Varian, Inc., Palo Alto, CA, USA). Concentration of Hg was measured on Flow Injection Mercury System (PerkinElmer FIMS 400 with AS-91 Autosampler) by mercury cold vapour generation and interference-free using $\mathrm{SnCl}_{2}$ as reducing agent. For each sample, soil $\mathrm{pH}$ was determined using a 1:5 soil weight/water volume ratio, organic carbon (OC) was determined by sulfochromic oxidation and available $\mathrm{K}_{2} \mathrm{O}$ and $\mathrm{P}_{2} \mathrm{O}_{5}$ by the ammonium lactate method [28]. Total nitrogen was determined by the Kjeldahl method [29]. The EC and pH were measured using a MettlerToledo MPC 227 conductivity / $\mathrm{pH}$ meter. Sodium and potassium concentrations were determined by atomic emission spectrometry (AAS PerkinElmer 3110). All concentrations were calculated on the basis of dry weight (d.w.) of the samples $\left(105^{\circ} \mathrm{C}, 24 \mathrm{~h}\right)$. The total amount of polycyclic aromatic hydrocarbon compounds in the sample was determined by liquid chromatography (HPLC). The congeners of polycyclic biphenyls (PCB-28, PCB-52, PCB-141 and PCB-180) and total polychlorinated biphenyls (PCBs) were determined by gas chromatography.

Biosolids characterization methods, including the SS stabilization methods, were described in detail by Černe et al. [23].

Quality control consisted of reagent blanks, duplicate samples and several referenced soil and sediment samples of a similar matrix. The maximum allowable relative standard deviation between replicates was set to $10 \%$.

\subsection{Soil Types}

A 1:25,000 digital soil map of the Šibensko-kninska County was used to identify dominant soil types in the study [30]. According to the World Reference Base [31], the dominant soil types of the study area are classified as Rhodic Cambisols clayic, Chromic Cambisols loamic and Rendzic mollic Leptosols loamic. Related to parent material and relief, Rhodic Cambisols clayic can be additionally specified as leptic, skeletic or colluvic, and Chromic Cambisols as leptic, colluvic or calcaric.

\subsection{Data Processing and Mapping}

The statistical analyses were conducted by using the Statistical Analysis Software [32]. Thematic soil maps, needed to evaluate the potential of agricultural land in the study area, were generated with the Geostatistical Analyst extension in the ArcGIS 10.8 program [33]. Interpolated maps of heavy metals and potentially toxic elements, PAHs and PCBs in 
surface soil layer were produced by applying Inverse Distance Weighting (IDW) method. This method assigns weights in an averaging function based on the inverse of the distance (raised to some power) to every data point located within a given search radius centered on the point of estimate [34].

\subsection{Legislation}

Specific legal rules for sludge treatment, disposal and usage are defined at both the EU (Directive 91/271/EEC, Directive 86/278/EEC) and at national level. Agricultural usage of sewage sludge has been regulated in Croatia by the Directive on sewage sludge usage in agriculture, as shown in Table 1 [21]. Table 2 shows limit values of $\mathrm{Cd}, \mathrm{Cu}, \mathrm{Ni}, \mathrm{Pb}, \mathrm{Zn}, \mathrm{Hg}$ and $\mathrm{Cr}$ in sludge-treated agricultural soil ( $\mathrm{mg} \mathrm{kg}^{-1}$ dry soil) [17].

Table 1. Limits of $\mathrm{Cd}, \mathrm{Cu}, \mathrm{Ni}, \mathrm{Pb}, \mathrm{Zn}, \mathrm{Hg}$ and $\mathrm{Cr}$, and of polychlorinated biphenyls (PCBs), for sludge used in agriculture ( $\mathrm{mg} \mathrm{kg}^{-1}$ d.w. of sewage sludge) [17].

\begin{tabular}{|c|c|c|}
\hline & & $\begin{array}{c}\text { Limit Value (mg kg-1 d.w. of } \\
\text { Sewage Sludge) }\end{array}$ \\
\hline \multirow{7}{*}{ Heavy Metal } & Cadmium $(\mathrm{Cd})$ & 5 \\
\hline & Copper $(\mathrm{Cu})$ & 600 \\
\hline & Nickel (Ni) & 80 \\
\hline & Lead $(\mathrm{Pb})$ & 500 \\
\hline & Zink (Zn) & 2000 \\
\hline & Mercury $(\mathrm{Hg})$ & 5 \\
\hline & Chromium (Cr) & 500 \\
\hline \multirow{5}{*}{ PCBs } & 2,4,4'-Trichlorobiphenyl & 0.2 \\
\hline & 2,2',5,5'-Tetrachlorobiphenyl & 0.2 \\
\hline & $2,2^{\prime}, 4,5,5^{\prime}$-Pentachlorobifenyl & 0.2 \\
\hline & $2,2^{\prime}, 3,4,5,5^{\prime}$-Hexachlorobifenyl & 0.2 \\
\hline & $2,2^{\prime}, 3,4,4^{\prime}, 5,5^{\prime}$-Heptachlorobifenyl & 0.2 \\
\hline
\end{tabular}

Table 2. Limits of $\mathrm{Cd}, \mathrm{Cu}, \mathrm{Ni}, \mathrm{Pb}, \mathrm{Zn}, \mathrm{Hg}$ and $\mathrm{Cr}$ in sludge-treated agricultural soil (mg kg ${ }^{-1}$ d.w. of soil) [17].

\begin{tabular}{cccc}
\hline Parameter & \multicolumn{3}{c}{ Limit Values } \\
& $\mathbf{( m g ~ k g}^{\mathbf{- 1}} \mathbf{d} . \mathbf{w}$. of Soil for Soil Heavy Metals Concentration) \\
\hline $\mathrm{pH} \mathrm{KCl}_{\mathrm{KCl}}(\mathrm{Cd})$ & $5.0<\mathrm{pH}<5.5$ & $5.5<\mathrm{pH}<6.5$ & $\mathrm{pH}>6.5$ \\
Cadmium & 0.5 & 1 & 1.5 \\
Copper $(\mathrm{Cu})$ & 40 & 50 & 100 \\
Nickel $(\mathrm{Ni})$ & 30 & 50 & 70 \\
Lead $(\mathrm{Pb})$ & 50 & 70 & 100 \\
$\mathrm{Zink}(\mathrm{Zn})$ & 100 & 150 & 200 \\
Mercury $(\mathrm{Hg})$ & 0.2 & 0.5 & 1 \\
Chromium $(\mathrm{Cr})$ & 50 & 75 & 100 \\
\hline
\end{tabular}

\section{Results}

\subsection{Land Resources and Agricultural Land Use}

Based on the current national legislation and on the data of the Croatian Agricultural Parcel Identification System (ARKOD) from 2017 [26], 25,736 ha of land may be considered for biosolids application in the study area (Figure 2). Further analysis of land use and parcel numbers per specific land use was carried out as shown in Table 3. According to this, the average parcel size is $0.65 \mathrm{ha}$. The largest area of agricultural land in the study area is occupied by karst pastures (16,871 ha), divided into 6820 parcels. In addition, olive groves are planted on 2662 ha, being divided into 14,404 parcels, giving an average parcel size of only 0.18 ha. The spatial distribution of parcels in relation to each land use category is shown in Figure 2. Obviously, such a pattern of parcel size and land use diversity may pose a serious constraint for the management of agricultural use of biosolids. 


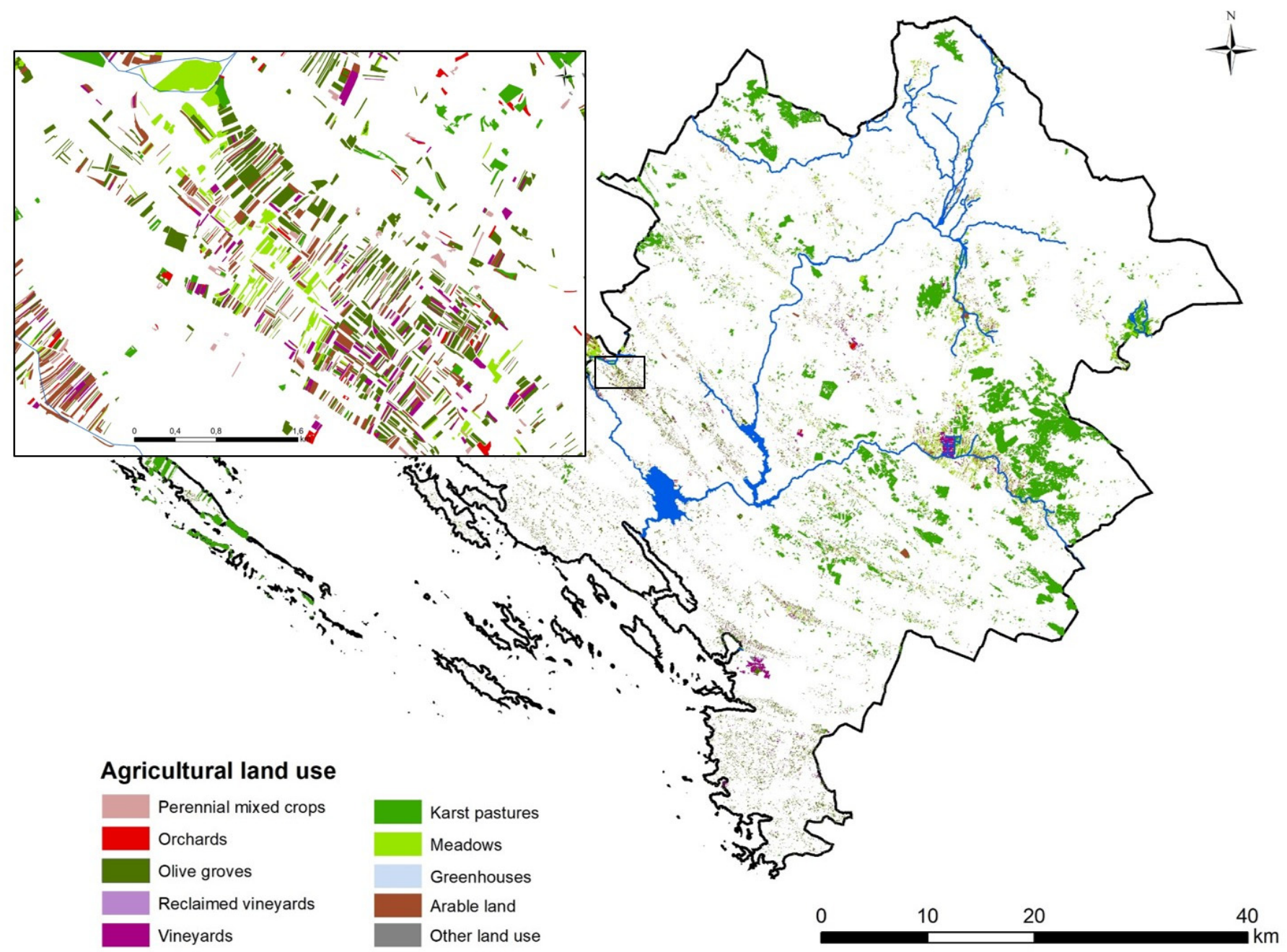

Figure 2. Agricultural land use pattern. Enlarged area presents agricultural parcels' spatial pattern in Petrovo polje.

Table 3. Utilized agricultural area by categories (ha) and number of parcels within the land use category (Šibenik region, Croatia).

\begin{tabular}{ccc}
\hline Agricultural Land Categories & Land Area (in Hectares) & Number of Parcels \\
\hline Arable land & 1752 & 5108 \\
Greenhouses & 2 & 55 \\
Meadows & 2762 & 6695 \\
Karst pastures & 16,871 & 6820 \\
Vineyards & 951 & 3289 \\
Abandoned vineyards & 19 & 7 \\
Olive groves & 2662 & 14,404 \\
Orchards & 221 & 1074 \\
Perennial crops & 476 & 2358 \\
Other & 20 & 20 \\
\hline Total & 25,736 & 39,830 \\
\hline
\end{tabular}

\subsection{Soil Properties}

The basic statistics of the soil properties of the study area are summarized in Table 4 . The soils are alkaline, with an average $\mathrm{pH}$ of 7.89 . The average $\mathrm{CaCO}_{3}$ content is $17.1 \%$ and the average soil organic matter content is $29.7 \mathrm{~g} \mathrm{~kg}^{-1}$, ranging from 11 to $117 \mathrm{~g} \mathrm{~kg}^{-1}$. The ranges of bioavailable nutrients concentrations were rather wide, which can be explained 
by a number of interrelated factors, such as soil types' variability, including natural nutrient supply capacity, variation in land use and inconsistent fertilization practices.

Table 4. Basic statistics on soil properties, heavy metal concentrations, polycyclic aromatic hydrocarbons (PAHs) and polychlorinated biphenyls $(\mathrm{PCBs})(\mathrm{N}=68)$. Threshold values set by legislation are given.

\begin{tabular}{|c|c|c|c|c|c|c|c|c|c|c|c|}
\hline \multirow[b]{2}{*}{ Variable } & \multirow[b]{2}{*}{ Symbol } & \multirow[b]{2}{*}{ Unit } & \multicolumn{7}{|c|}{ Descriptive Statistics } & \multicolumn{2}{|c|}{ Threshold Value } \\
\hline & & & Mean & Median & $\begin{array}{l}\text { Std. } \\
\text { Dev. }\end{array}$ & Min & Max & Skewness & Kurtosis & NN 71/19 a & $\mathbf{E U}^{\mathbf{b}}$ \\
\hline $\mathrm{pH}$ & $\mathrm{pH}$ & & 7.89 & 7.89 & 0.25 & 7.23 & 8.33 & -0.132 & -0.63 & & \\
\hline $\begin{array}{c}\text { Electrical } \\
\text { conductivity }\end{array}$ & $\mathrm{EC}$ & $\mathrm{dS} \mathrm{m}^{-1}$ & 0.16 & 0.15 & 0.05 & 0.04 & 0.42 & 1.99 & 9.41 & & \\
\hline $\begin{array}{l}\text { Calcium } \\
\text { carbonate }\end{array}$ & $\mathrm{CaCO}_{3}$ & $\%$ & 17.1 & 11.0 & 16.9 & 0.83 & 59.8 & 1.09 & 0.10 & & \\
\hline Organic matter & $\mathrm{OM}$ & $\mathrm{g} \mathrm{kg}^{-1}$ & 29.7 & 26.7 & 16.7 & 11.0 & 117 & 2.54 & 10.2 & & \\
\hline Clay & & $\%$ & 32.4 & 35.0 & 10.8 & 6.00 & 51.0 & -0.74 & -0.02 & & \\
\hline $\begin{array}{l}\text { Available } \\
\text { phosphorus }\end{array}$ & $\mathrm{P}_{2} \mathrm{O}_{5}$ & $\mathrm{mg} 100 \mathrm{~g}^{-1}$ & 30.4 & 6.25 & 79.4 & 0.05 & 618 & 6.22 & 44.7 & & \\
\hline $\begin{array}{l}\text { Available } \\
\text { potassium }\end{array}$ & $\mathrm{K}_{2} \mathrm{O}$ & $\mathrm{mg} 100 \mathrm{~g}^{-1}$ & 48.5 & 33.9 & 34.2 & 9.54 & 186 & 1.66 & 2.97 & & \\
\hline Cadmium & $\mathrm{Cd}$ & $\mathrm{mg} \mathrm{kg}^{-1}$ & 1.52 & 1.36 & 1.07 & 0.08 & 8.43 & 4.01 & 24.9 & 1,5 & $20-40$ \\
\hline Chromium & $\mathrm{Cr}$ & $\mathrm{mg} \mathrm{kg}^{-1}$ & 67.1 & 67.9 & 27.5 & 13.2 & 129 & 0.22 & -0.46 & 100 & I \\
\hline Copper & $\mathrm{Cu}$ & $\mathrm{mg} \mathrm{kg}^{-1}$ & 96.0 & 42.6 & 162 & 9.01 & 1165 & 4.75 & 27.8 & 100 & $1000-1750$ \\
\hline Mercury & $\mathrm{Hg}$ & $\mathrm{mg} \mathrm{kg}^{-1}$ & 0.10 & 0.06 & 0.18 & 0.00 & 1.39 & 6.14 & 43.1 & 1 & $16-25$ \\
\hline Nickel & $\mathrm{Ni}$ & $\mathrm{mg} \mathrm{kg}^{-1}$ & 46.6 & 44.9 & 20.3 & 11.1 & 126 & 1.20 & 2.97 & 70 & $300-400$ \\
\hline Lead & $\mathrm{Pb}$ & $\mathrm{mg} \mathrm{kg}^{-1}$ & 37.1 & 32.6 & 25.5 & 7.12 & 172 & 2.79 & 11.4 & 100 & $750-1200$ \\
\hline Zinc & $\mathrm{Zn}$ & $\mathrm{mg} \mathrm{kg}^{-1}$ & 90.0 & 88.5 & 33.0 & 24.7 & 208 & 0.60 & 1.38 & 200 & $2500-4000$ \\
\hline $\begin{array}{c}\text { Polycyclic } \\
\text { aromatic } \\
\text { hydrocarbon }\end{array}$ & PAH & $\mathrm{mg} \mathrm{kg}^{-1}$ & 0.21 & 0.05 & 0.39 & 0.05 & 1.01 & 2.45 & 6.00 & 0.2 & \\
\hline $\begin{array}{l}\text { Polychlorinated } \\
\text { biphenyl }\end{array}$ & PCB & $\mathrm{mg} \mathrm{kg}^{-1}$ & 0.10 & 0.10 & 0.00 & 0.10 & 0.10 & 1.37 & -3.33 & 0.2 & \\
\hline
\end{tabular}

${ }^{a} \mathrm{NN}(71 / 19)$ - Maximal permitted concentrations as defined by Croatian Government regulations $\left(\mathrm{mg} \mathrm{kg}^{-1}\right){ }^{\mathrm{b}}$ EU Directive 86/278/EEC— Council Directive on the protection of the environment, and in particular of the soil, when sewage sludge is used in agriculture.

The mean value of the total trace metal contents in the soils followed a descending order: $\mathrm{Zn}>\mathrm{Cu}>\mathrm{Cr}>\mathrm{Ni}>\mathrm{Pb}>\mathrm{Cd}>\mathrm{Hg}$ (Table 4). Of all the heavy metals examined in the study, only $\mathrm{Cr}$ and $\mathrm{Zn}$ showed normal distribution (skewness $<1$ ). The mean value of $\mathrm{Cd}$ content was $1.52 \mathrm{mg} \mathrm{kg}^{-1}$ and ranged from 0.08 to $8.43 \mathrm{mg} \mathrm{kg}^{-1}$. The phenomenon of anomalously high $\mathrm{Cd}$ concentrations in soils developed on limestone has been described previously $[35,36]$. The mean value of $\mathrm{Cu}$ content was $96 \mathrm{mg} \mathrm{kg}^{-1}$, but the median value was more than twice lower, amounting to $42.6 \mathrm{mg} \mathrm{kg}^{-1}$.

Considering that a median value can represent a baseline, the large number of samples with anomalous $\mathrm{Cu}$ contents was evident, caused by application of copper salts as fungicides in vineyards and orchards over decades [37]. The mean value of Cr content was $67.1 \mathrm{mg} \mathrm{kg}^{-1}$, with a range from 13.2 to $129 \mathrm{mg} \mathrm{kg}^{-1}$. In the Croatian Karst region, with soils developed from carbonate bedrock, the median value for Cr was $121 \mathrm{mg} \mathrm{kg}^{-1}$ [36]. Higher Cr content is an intrinsic property of heavier-textured soils, such as Terra Rossa's appearance in the study area. Median and average values of $\mathrm{Ni}$ content in the soils of the study area are very close at 44.9 and $46.6 \mathrm{mg} \mathrm{kg}^{-1}$, respectively. The maximum Ni content determined in the study was $126 \mathrm{mg} \mathrm{kg}^{-1}$. In current national legislation, the permitted limit for $\mathrm{Ni}$ in agricultural soils in Croatia is set at $50 \mathrm{mg} \mathrm{kg}^{-1}$ dry weight and the accumulation of this metal in soils receiving wastes such as sewage sludge can give rise to potential hazards for human, animal and plant health. The highest soil $\mathrm{Pb}$ concentration of $172 \mathrm{mg} \mathrm{kg}^{-1}$ was found near the military facility, and the accumulation of $\mathrm{Pb}$ in surrounding soils may be associated with ammunition use or disposal. The median value for $\mathrm{Zn}$ reported in this study is $90 \mathrm{mg} \mathrm{kg}^{-1}$, which is lower than the baseline value for the 
Coastal Croatia of $108 \mathrm{mg} \mathrm{kg}^{-1}$. The $\mathrm{Zn}$ concentrations of the soils follow a normal distribution (skewness $=0.60$ ). The interpolation maps for the studied metals are shown in Figure 3 .
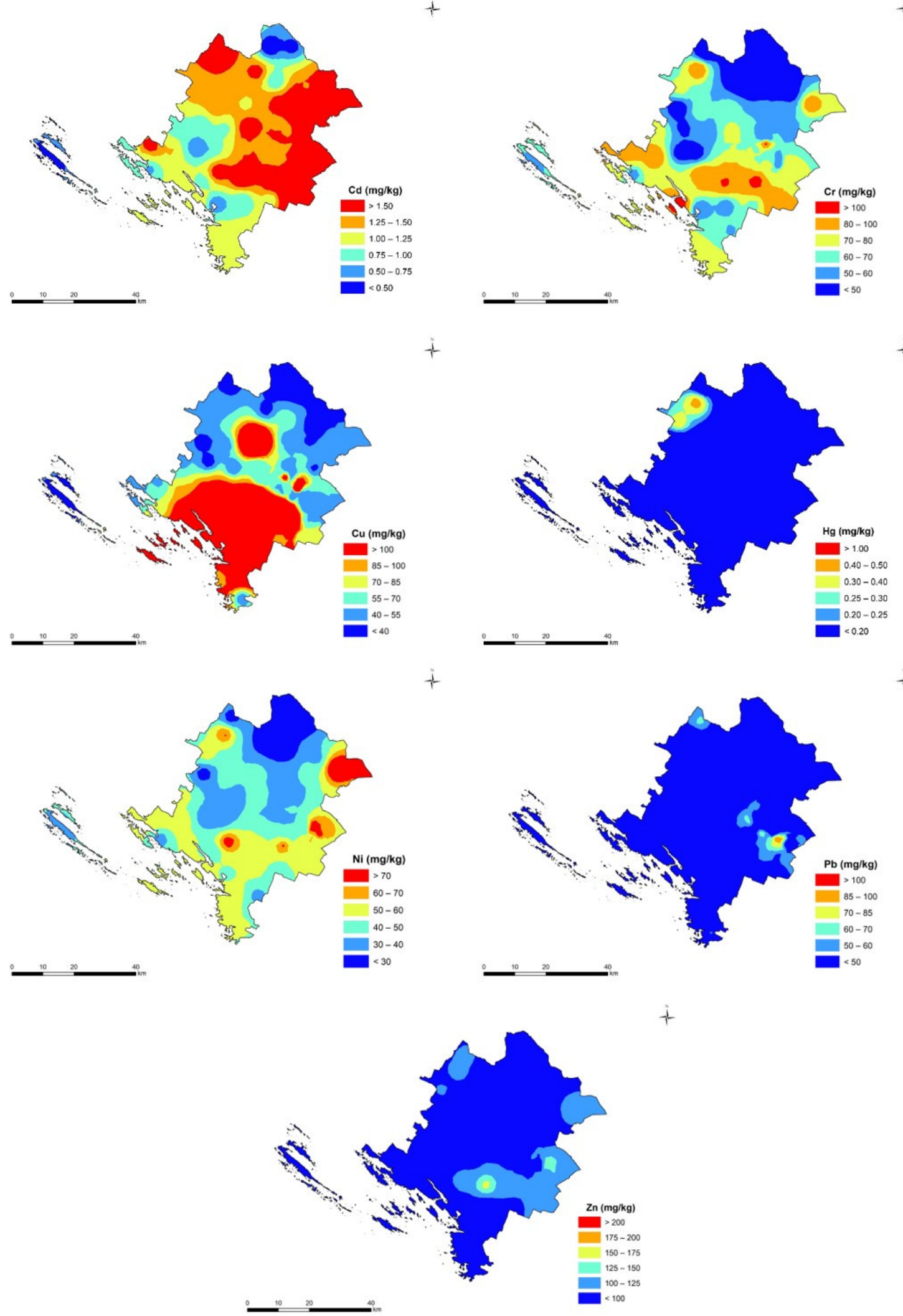

Figure 3. Interpolated maps of soil heavy metals. 


\subsection{Land Parcels Suitable for Biosolids Application}

Based on the criteria set by legislation and the land use inventory, the land parcels suitable for biosolids application were identified (Table 5), and a total of 6032 ha of land was available. However, the land is divided into 26,233 parcels, which is another significant constraint to the sustainable biosolids management and use in agriculture in the study area, as shown in Figure 4.

Table 5. Agricultural land considered as potentially available for biosolids application.

\begin{tabular}{ccc}
\hline Agricultural Land Use & Area (in Hectares) & Number of Parcels \\
\hline Arable land & 1752 & 5108 \\
Vineyards & 951 & 3289 \\
Olives & 2662 & 14,404 \\
Orchards & 221 & 1074 \\
Combined permanent crops & 476 & 2358 \\
\hline Total & 6032 & 26,233 \\
\hline
\end{tabular}

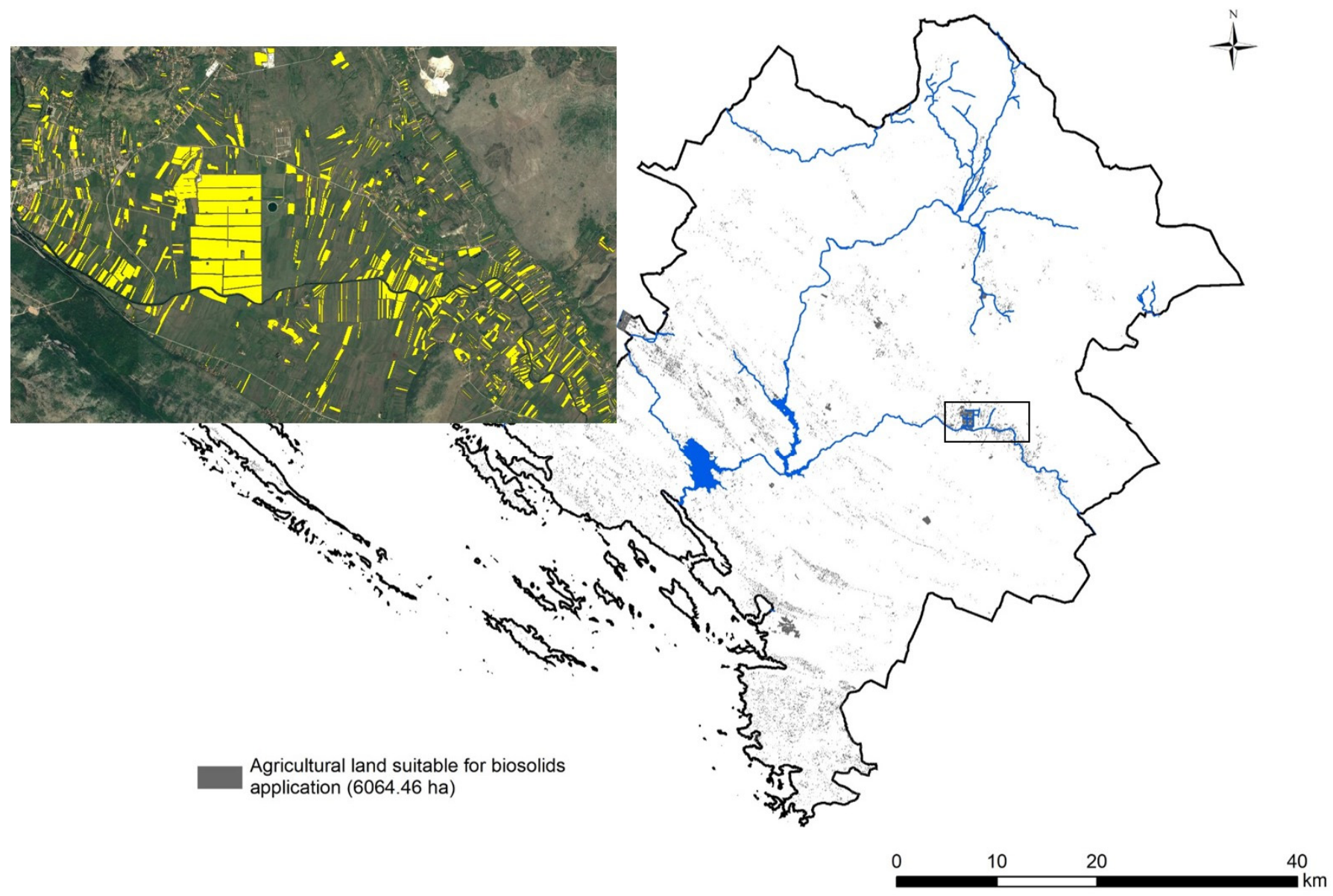

Figure 4. Agricultural land parcels suitable for biosolids application. The enlarged section shows the differences in size and spatial distribution of these parcels in Petrovo polje.

The next set of criteria applied in land suitability assessment was related to the potentially toxic elements and organic compounds in soils receiving biosolids. The limitation was found mainly regarding the concentration of $\mathrm{Cd}$ in soils that exceeds the highest permissible concentration (Table 4). Sites where the concentrations of heavy metals and organic residues in soil exceed the limits are excluded from further inventory. 


\section{Discussion}

Efficient land use depends primarily on land availability and soil quality. The land use inventory undoubtedly plays an important role in comprehensive planning and can be used to distinguish spontaneous or natural drivers of land use change from those stimulated by public policies. Soil survey information is widely applied in Croatia. In recent years, the supply of suitability maps has increased, reflecting the spread of environmental and agricultural interest $[38,39]$. Every decision on the application of any measures in the environment related to soil quality and management, whether statutory regulations or practical actions, must be based on reliable and comparable data on the status of this part of the environment in the given area $[40,41]$.

The priority target pollutants in biosolids used in agriculture may depend on several specific conditions, such as regional activities (socio-economic conditions and demography, industry, land use and climate), properties of the receiving soil, land geomorphology and hydrology [42]. Recent studies provided evidence for the accumulation of microplastics in agricultural soils over time after biosolids application [43,44]. Moreover, a new debate has been recently arisen in various research groups regarding the possible detection of SARS-CoV-2 virus in wastewater samples [45]. As the broad and fragmented EU legislative framework cannot in detail regulate specific regional conditions, new findings put pressure on policymakers to accustom their national legislation accordingly.

Recently opened, the re-evaluation of the EU Sewage Sludge Directive (86/278/EEC) is expected to make progress in addressing new contaminants in biosolids as well as the management options to reduce environmental harm [5]. Significant differences in quality and quantity of produced biosolids, as well as the possibilities for their use in agriculture, are evident even on the national level. In 2018, for Croatia, the total production of 19.23 thousand tons of dry SS was reported, of which 1.548 thousand tons were disposed on agricultural land [46]. In addition, a recent study [23] provided a comprehensive physico-chemical characterization of stabilised sewage sludge collected from different WWTPs in Croatia.

As such, considering the complexity of the soil system, the legal regulation of the maximum amount of biosolids that can be spread on land is certainly extremely demanding. The authors of [10] analysed the current legislation for the application of biosolids on agricultural land in Europe and found significant differences in many aspects of regulation among countries, including the maximum amount of biosolids spread on land, the soil where the use of biosolids is prohibited and the treatment requirements. Regulations that ensure the safe and responsible management of biosolids have been continuously upgrading. Nevertheless, it seems that the legislation can hardly follow the momentum of occurrence of new classes of water contaminants, or so-called contaminants of emerging concern [47].

Croatian regulation aligned to the EU Directive 86/278/ECC says that the agricultural use of sludge that could cause the permissible levels of heavy metals in the soil to be exceeded is prohibited, and that it is permitted to use a maximum of treated sewage sludge of $1.66 \mathrm{t}_{\mathrm{DM}} \mathrm{ha}^{-1}$ year $^{-1}$, but it is vague about the frequency of biosolids application on agricultural land. Further restrictions refer to the characteristics of soil receiving biosolids, the composition of the sludge, the food crops produced and the SS treatment method. There is no specific legislation on the regional level in spite of the great regional differences between the continental and coastal parts of Croatia in terms of land availability and soil types, climatic conditions and types of land on which biosolids can be applied.

\subsection{Major Challenges in the Coastal Karst Region}

A karst environment is characterized by high complexity of relief forms, steep slopes, shallow stony soils and sparse natural vegetation; therefore, karst areas have been subjected to anthropogenic modifications to increase their agricultural potential [20]. A typical feature of Adriatic Dinaride karst is the phenomenon of karst fields (polje) [48], on the bottom of which the only arable soil of the karst area accumulates. Polje's fertile soils were developed 
by fluvial sedimentation and by deposition of the eroded soil material from the karst hills within the catchment. Moreover, polje is characterized by periodic inundation and therefore in most of this area's land consolidation was carried out and drainage systems were installed. In the Šibenik region, one of the largest poljes of the Dinaric karst, Petrovo polje, is located (Figure 4). Petrovo polje's flor spreads on approximately 3200 hectares. From the geomorphological aspect, Petrovo polje is an alluvial plain characterized by a few inundation terraces and elevated cascades, which are not flooded regularly. As shown on the zoomed part in Figure 4, drainage, reclamation and land consolidation were done in the past on only 170 hectares, and these parcels are considerably greater than the average parcel size (0.65 ha). Small size parcels scattered across the region cannot be considered as suitable for sustainable biosolids application. Basic criteria in suitability assessment are based on legislation, but each region has to be carefully evaluated, taking into account specific features not covered by the law.

In the coastal region, characterized by semi-arid climate, the progressive depletion of soil organic matter is the major threat to the sustainability of the agricultural production system. The map of soil organic carbon content (SOC) of European soils, from which Croatia was unfortunately excluded, shows that Mediterranean regions of Europe exhibit distinctively smaller values of SOC than those of other regions, with substantial areas having very low OC $(\leq 1 \%)$ or low OC $(\leq 2 \%$, [49]). Soil organic matter (SOM) comprises a wide range of pools, and indices of the quality and potential turnover rates of SOM pools add great value to the sole knowledge of the SOM content of a soil [50].

The decrease in SOM content in the soils of the Mediterranean region can be related to the number of drivers: current dynamic rural transformation and continuous and intensive depopulation, followed by high rate of land and farm abandonment [49]. Additionally, climate change affects disproportionately Croatian regions. In the coastal region, the intensity and duration of anomalous weather events, including extreme precipitation, droughts or high temperature occurrences, become more frequent in the past decades [37]. Dissected karst landscape makes the land prone to erosion by frequent torrential storms, particularly in vineyards and orchards, which promote SOM decrease. The highest annual soil loss rates are observed in the Mediterranean areas, and vineyards are among the land use types with the highest mean soil loss rate (about $9.5 \mathrm{tha}^{-1}$ year $^{-1}$ vs. $2.5 \mathrm{t} \mathrm{ha}^{-1}$ year $^{-1}$ on average for all land use types) [51].

Management practices that favor a slow decay rate of SOM increase $C$ sequestration in soils, but on the other hand the supply of nutrients may be reduced. Therefore, the continuous supplying of carbon in the form of organic matter is needed. Animal waste produced on-farm, such as animal manure and slurries (including their derivatives) is becoming less and less available due to devoid of livestock production. Biosolids application is thus one of a broad range of practices that can be used either separately or combined with other measures for optimizing the SOM content of agricultural soils. As the cost of transportation of biosolids may be reduced due to proximity of wastewater treatment facility, peri-urban agriculture could benefit from these sources. In any case, potential risk in the food chain and the environment should be carefully assessed before biosolids are introduced into the soil.

\subsection{Nutrient Value of Biosolids and Heavy Metals Concentrations}

Biosolids are nutrient-rich organic material considered as a beneficial soil amendment. The availability of nutrients in the sludge depends though on the wastewater treatment process. Many of the trace metals in biosolids are also present in conventional fertilizers and manure. At the low concentrations and low rates these substances are nontoxic, and the environmental risk is low if good farming practices are. In general, nitrogen and phosphorus are the main nutrients that impact groundwater or surface water quality. Comparing with commercial fertilizers, nitrogen in biosolids is present in a slow-release organic form, which makes it less mobile. 
Many studies nowadays address phosphorus recovery from wastewater solids, and besides the struvite precipitation of dissolved phosphate, new technologies have been developed to recover phosphorus from the particulate phase in wastewater solids [52]. The concentrations of phosphorus in stabilized sewage sludge from different Croatian wastewater plants (Table 6) ranged from 3.23-36.1 $\mathrm{g} \mathrm{kg}^{-1}$.

Table 6. Mean, range and variability of nutrient concentrations ${ }^{\mathrm{a}}$ in stabilized sewage sludge collected from different Croatian wastewater plants.

\begin{tabular}{|c|c|c|c|c|c|}
\hline Nutrient & $\mathrm{pH}$ & Organic C (\%) & Total N (\%) & $\begin{array}{l}\text { Total } \mathrm{K}^{\mathrm{b}} \\
\left(\mathrm{g} \mathrm{kg}^{-1}\right)\end{array}$ & $\begin{array}{l}\text { Total } P^{b} \\
\left(g^{b} g^{-1}\right)\end{array}$ \\
\hline Mean & 6.9 & 37.0 & 5.9 & 3.3 & 26.2 \\
\hline Range & $6.6-7.2$ & $25.8-44.5$ & $3.3-7.7$ & $1.7-4.6$ & $20.7-36.1$ \\
\hline Std. Dev. & 0.2 & 7.7 & 1.8 & 1.2 & 6.27 \\
\hline
\end{tabular}

${ }^{\mathrm{a}}$ Concentrations are on a dried solids basis; ${ }^{\mathrm{b}}$ aqua regia digestion.

With regards to the nutrient levels (Table 6), the biosolids are highly elevated in $P$ contents, indicating the potential for being an alternative to $P$ fertilisers. In many studies, researchers have shown that $\mathrm{P}$ concentrations in the soils increase with SS amendment [53-55]. A similar trend was also observed in soils amended with SS compost [56,57] or SS biochar [58]. However, repeated biosolids applications may pose a threat to the environment due to potential $P$ release through leaching and the subsequent water eutrophication $[59,60]$. Nevertheless, our previous study found that the addition of SS-derived compost or biochar to soils did not increase the P mobility due to the high sorption in amended Terra Rossa and Rendzina substrates [61]. From an environmental perspective, the P-based SS application is safer for agricultural use than the dose based on the SOM which may potentially affect the migration of $\mathrm{P}$ to deeper soil layers, leading to the groundwater pollution [57]. Table 6 reports that biosolids are a good source of $\mathrm{N}$ as well, where aerobically stabilised SS contains more $\mathrm{N}$ than reported in the primary and anaerobic SS [23]. Among the macronutrients of agronomic importance, $\mathrm{K}$ is less abundant in SS (Table 6) and the long-term use of biosolids as a soil amendment can lead to a K deficiency, resulting in yield decrease [62]. Since SS is relatively deficient in K, the higher application levels are needed to ensure adequate $\mathrm{K}$ content for plant growth [63]. Therefore, other studies do confirm an increase in $\mathrm{K}$ levels in amended soils when using higher doses of SS compost $[64,65]$ or SS biochar $[56,66]$.

Besides the nutrient contents, the permissible uses of biosolids should be based on heavy metal concentrations (Table 7). The maximum allowable loadings for heavy metals per hectare of land per year are specified in Directive 86/278/EEC as well as the proposed limits based on their working document of sludge for the year 2025 [67].

Table 7. Mean, range, and variability of heavy metals concentration ${ }^{a}$ in stabilized sewage sludge collected from different Croatian wastewater plants.

\begin{tabular}{|c|c|c|c|c|c|c|c|}
\hline$\underset{b}{\text { Heavy metal }}$ & $\mathrm{Cd}$ & $\mathrm{Cr}$ & $\mathrm{Cu}$ & $\mathrm{Hg}$ & $\mathbf{N i}$ & $\mathbf{P b}$ & $\mathrm{Zn}$ \\
\hline & \multicolumn{7}{|c|}{$\mathrm{mg} \mathrm{kg}^{-1}$} \\
\hline Mean & 0.9 & 55.3 & 275 & 1.3 & 30.7 & 46.0 & 1001 \\
\hline Range & $0.7-1.3$ & $22.9-109$ & $156-660$ & $0.4-1.9$ & $17.6-52.6$ & $11.8-72.1$ & $801-1254$ \\
\hline Std. Dev. & 0.2 & 35.7 & 185 & 0.7 & 13.4 & 22.1 & 170 \\
\hline$N N(38 / 08)^{c}$ & 5 & 500 & 600 & 5 & 80 & 500 & 2000 \\
\hline $\begin{array}{l}\text { EU Directive } \\
\text { 86/278/EEC }\end{array}$ & $20-40$ & / & $1000-1750$ & $16-25$ & $300-400$ & $750-1200$ & $2500-4000$ \\
\hline
\end{tabular}

${ }^{a}$ Concentrations are on a dried solids basis; ${ }^{b}$ aqua regia digestion; ${ }^{c} \mathrm{NN}(38 / 08)$-Croatian legislation on sewage sludge agricultural use; ${ }^{d}$ EU Directive 86/278/EEC - Council Directive on the protection of the environment, and in particular of the soil, when sewage sludge is used in agriculture.

Considering the metal levels in the studied soils (Table 4), which are one of the limiting factors for SS agricultural use, the results showed that high variability is present for all 
metals of concern. From Table 4, it can be seen that average concentrations of $\mathrm{Cd}, \mathrm{Cr}$, $\mathrm{Cu}, \mathrm{Hg}, \mathrm{Ni}, \mathrm{Pb}$ and $\mathrm{Zn}$ remained in accordance with the limit set by current Croatian legislation (Table 2). Further, the heavy metal concentration in soil may be higher than a limit value specified in Table 2. In such cases, the application of biosolids on land should be allowed after considering various additional aspects, such as the uptake of heavy metals by plants/crops, their intake rate by animals, the risk of groundwater contamination or the assessment of the long-term effects on ecosystem biodiversity. Obviously, the evaluation of such possibilities should be done for each specific area or case.

Higher heavy metals concentration, particularly of $\mathrm{Cr}$ and $\mathrm{Ni}$, are an intrinsic property of heavier textured soils, although they may originate from anthropogenic sources, too. According to the WRB soil classification system [31] dominant soil types in the agricultural land of the study area are Rhodic Cambisols clayic, Chromic Cambisols loamic and Rendzic mollic Leptosols loamic. Croatian national classification system [68] recognizes these soils as Terra Rossa, Calcocambisol and Rendzina. The term Terra Rossa has been widely applied to red soils overlying limestone and dolomite as a discontinuous layer ranging in thickness from a few centimeters to several meters, particularly in the Mediterranean region, and the Croatian Adriatic Sea coast, as well [69]. Cr abundance in the Terra Rossa matrix is explained as addition from external sources. According to Miko et al. [69], high Cr concentrations in Terra Rossa, but also widely in the karst region, are due to the polygenetic nature of Terra Rossa (e.g., presence of boehmite). It is possible, therefore, that $\mathrm{Cr}$ and $\mathrm{Ni}$ could be enriched because of weathering of karst bauxite deposits, present all along the Coastal Croatia karst region [70]. Furthermore, the phenomena of anomalously high $\mathrm{Cd}$ concentrations in soils developed on carbonate bedrock have been recorded in many studies [71-73]. For soil Cd, which varied from 0.08 to $8.43 \mathrm{mg} \mathrm{kg}^{-1}$ d.w. (Table 4), its sorption increases with $\mathrm{pH}$ [74] which may be evident in compost-amended soils [64]. The soil organic matter (SOM) which increases with SS compost addition $[57,74]$ was also found as one of the most important factors influencing the phytoavailability of Cd [75]. In the stabilised SS, Cd mobility is low since its major part is associated with Fe and Mn oxides and hydroxides [76]. However, the risk from $\mathrm{Cd}$ leaching was reported at neutral to alkaline $\mathrm{pH}$ after repeated applications of SS compost $[77,78]$. The biosolids amendment may possibly increase the mobility of $\mathrm{Cd}$ in soils through the formation of Cd-chloro-complexes [79] due to the presence of soluble chloride salts in SS [80]. Nevertheless, a reduction in extractable $\mathrm{Cd}$ in the soil was also revealed as a result of SS compost application [81].

Concerning $\mathrm{Cr}$, being in the range from 13.2 to $129 \mathrm{mg} \mathrm{kg}^{-1} \mathrm{~d} . \mathrm{w}$. (Table 4), it was reported that in soils amended with composted SS, the Cr mobility increased under acid rain conditions [82]. In Croatia, aerobic or anaerobic stabilisation are the dominant procedures for sludge tretament, while stabilisation using lime is also a common technology, but it is used only by a few wastewater treatment plants. According to [83], caution should be advised when amending soil with lime-stabilised SS since liming of unstabilised SS can increase the $\mathrm{pH}$ to 12 , thus promoting oxidation of trivalent $\mathrm{Cr}$ to the highly toxic hexavalent $\mathrm{Cr}$.

Copper is one of the major toxic metals, and a highly reactive one, as well. Elevated levels of $\mathrm{Cu}$ in agricultural soils result from the use of $\mathrm{Cu}$-containing compounds to control plant diseases and from application of manure or sewage sludge. These applications may lead to gradual accumulation of $\mathrm{Cu}$ in the soil and thereby increase $\mathrm{Cu}$ toxicity toward crops and beneficial microorganisms [37]. In the case of $\mathrm{Cu}$ levels which fall within limits from 9.01 to $1165 \mathrm{mg} \mathrm{kg}^{-1}$ (Table 4), [64] reported that higher doses of SS compost may reduce the plant available $\mathrm{Cu}$ due an increase in soil pH. Similarly, [84] revealed that higher $\mathrm{Cu}$ leaf accumulation was found in less-amended soils, while lower in more fertilised soil. At low $\mathrm{pH}, \mathrm{Cu}$ solubility increases in amended soils until a threshold $\mathrm{pH}$ value is achieved ( $\mathrm{pH}$ of 5.5), at which $\mathrm{Cu}$ precipitates [85,86]. In soils amended with SS biochar, the bioavailability of soil metals decreases due to rise of soil $\mathrm{pH}$ and by sorption to the biochar surface [87]. However, [66] found that $\mathrm{Cu}$ concentrations in the radish leaves increased with the application level. It was also pointed out, that in agricultural soils with a long history 
of biosolids application the soluble $\mathrm{Cu}$ can be released through precipitation [74]. Most of the vineyards in the study area are planted on the hilly karst area on the steep slopes and shallow stony soils, managed in traditional way (Figure 5A), or on karst terraces reclaimed by stone crashing (Figure $5 \mathrm{~B}$ ). Only vineyards planted in karst poljes' are considered as suitable for biosolids use, such as in Petrovo polje, shown on Figure 4.

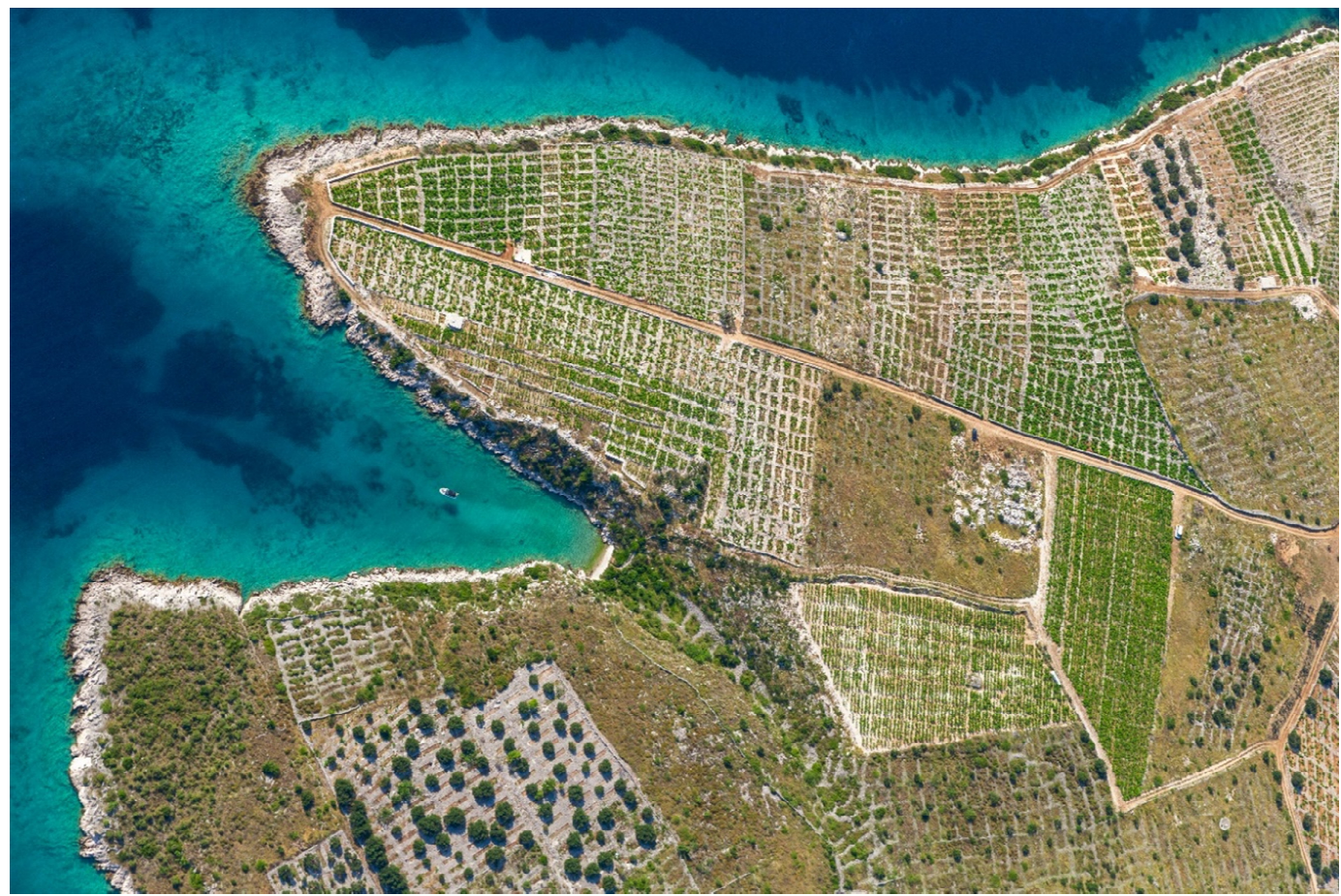

(A)

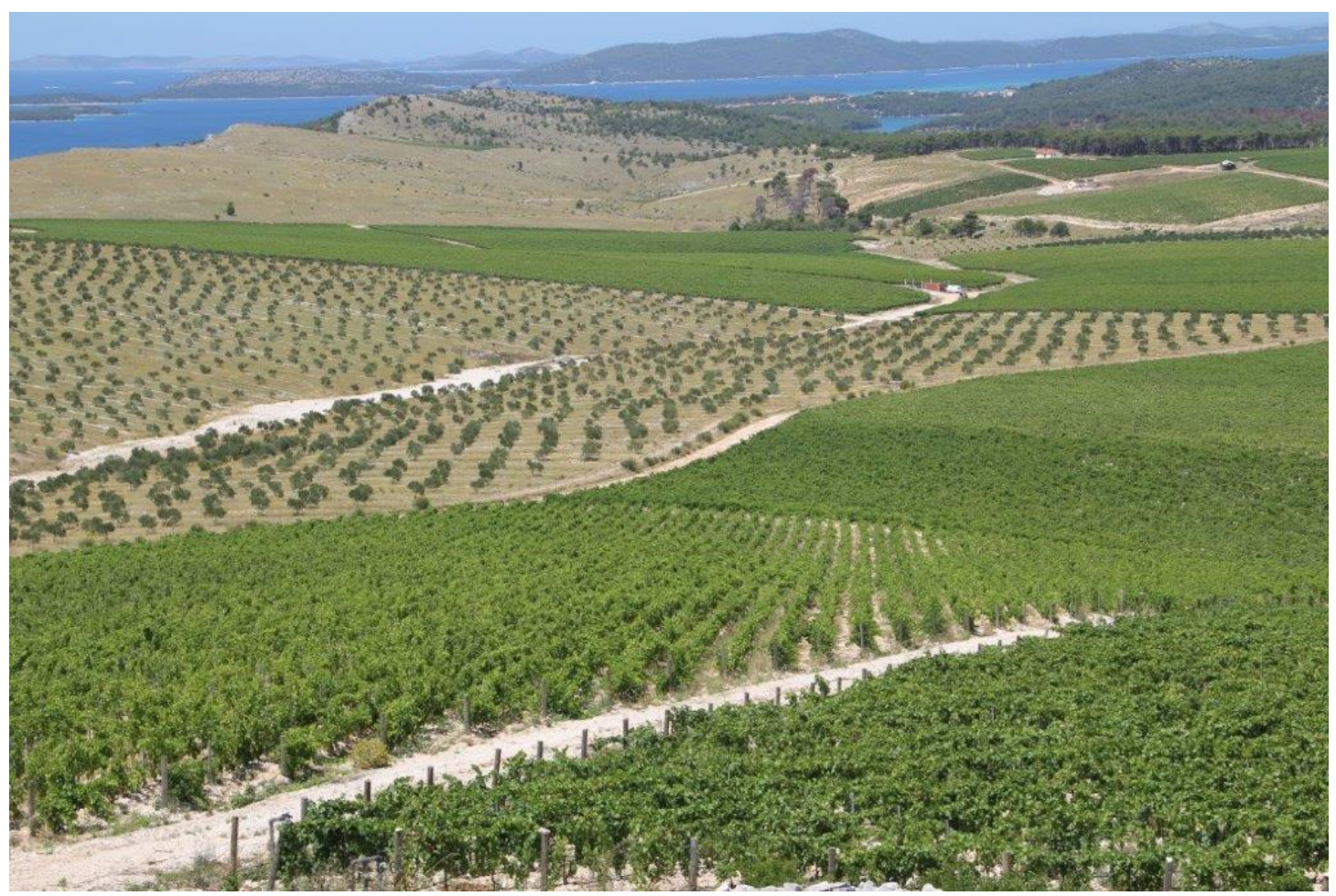

(B)

Figure 5. Photographs of (A) Vineyards and olives plantations on karst steep slopes within stony walls (Location Primošten); (B) Grapevine and olives plantations on karst plateau reclaimed by stone crushing (Location Jadrtovac, Šibenik). 
Even though $\mathrm{Hg}$ concentrations remained below the regulation limit (Table 4), the potentially elevated $\mathrm{Hg}$ levels in SS arising from possible $\mathrm{Hg}$ sources such as old paints and pigments, wood preservatives, mercury thermometers (nowadays forbidden in most EU countries), pesticides and glass mirrors [88] need to be carefully considered before SS is continuously used as an amendment of soil.

As regards the Ni varying from 11.1 to $126 \mathrm{mg} \mathrm{kg}^{-1}$ d.w. (Table 4), ref. [89] revealed that lime-stabilised SS may pose environmental hazard since liming can enhance the solubility of $\mathrm{Ni}$, making biosolids unsuitable for agricultural use. Interestingly, for soils with repeated applications of SS compost, it was found that the loss of Ni through leaching was low due to its immobilisation [74].

Regarding $\mathrm{Pb}$, the minimal risk is associated with low mobility of $\mathrm{Pb}$ in biosolids attributed to its higher fraction adsorbed to the silicate lattice or crystalline Fe and Mn oxides [76]. For instance, [84] found that transfer of $\mathrm{Pb}$ to edible parts of Chinese cabbage (Brassica rapa L. subsp. pekinensis (Lour.)) was limited when amending soil with SS-derived compost or biochar. However, [82] observed that the application of SS compost to a flower garden and abandoned phosphate mine soils enhance the mobility of $\mathrm{Pb}$.

An increased mobility of $\mathrm{Zn}$ in biosolids [76] means that health hazard over its phytoaccumulation should be taken into account when using SS as a fertiliser for soil [84,90,91]. According to [91], amendment rates higher than 150 tonnes/ha of SS compost should not be used, in order to prevent the potential $\mathrm{Zn}$ loading in the surface soil. In soils treated with SS compost, the high preference of $\mathrm{Zn}$ for sorption on the Fe and Mn oxides and hydroxides was reported at high $\mathrm{pH}$ [90]. In earlier study, a reduction of $\mathrm{Zn}$ concentrations in lettuce (Lactuca sativa L., "Tanya") compared to the control was documented at increased $\mathrm{pH}$ for the same agronomic practice [92]. In the case of SS biochar, [93] observed that the amounts of DTPA-extractable Zn increased in amended soils. In a similar study [94], an increase in the bioavailable fraction of $\mathrm{Zn}$ was found, while [21] revealed that the risk of $\mathrm{Zn}$ leaching is low.

\subsection{Karst Hydrology and Environmental Risk}

Increasing water demand and urbanisation in the coastal regions of the Mediterranean are already exerting pressure on coastal and alluvial aquifers, which are being degraded by over-pumping [95], groundwater pollution, alluvial and marine sediment quality [96,97], seawater intrusion [98], and intense and continuing interactions with various types of human activities [99]. Under such conditions, it is necessary to determine and understand the extent of all anthropogenic impacts on the natural and cultivated karst environment prior to the application of biosolids.

Because soils vary across the landscape, each soil type contains unique trace element concentrations based on its parent material and other soil-forming factors that may have added or removed these elements from the soil. High background concentrations of trace elements characteristic of soils developed on limestone could result in mobilization and release to surface and subsurface waters and subsequent incorporation into the food chain. Soil properties such as organic matter, type and amount of clay, $\mathrm{pH}$, and cation exchange capacity (CEC) affect the quantity of trace elements available for mobilization and release or sorption in a soil.

In karst catchments, groundwater and surface water are hydraulically connected by numerous karst features, which can increase the risk of contaminant transport from soil to groundwater, surface water, and lacustrine sediments or even coastal marine sediments. Fluvial systems can be strongly influenced by human activities and can act as a carrier and/or receptor of contaminants $[96,97,100]$.

Specific operational methods can be proposed to ensure the proper application of biosolids to protect the environment and human health in the Mediterranean karst region by defining the available land and land use, soil properties, possible geomorphological constraints (slope, rock outcrops and fractures, stoniness and underground karst formations, groundwater depth), as well as biosolids characteristics, application rates and placement 
methods. Leaching of nutrients and potentially toxic substances is often cited as a major problem in the proper application of sewage sludge. In [100], it is stated that mismanagement of biosolids land application can lead to leaching of $\mathrm{NO}_{3}-\mathrm{N}$ into groundwater and accumulation of $\mathrm{P}$ in surface soil, which can increase the risk of runoff/erosion loss of $\mathrm{P}$ and cause eutrophication [100].

One of the major concerns regarding biosolids land application is the accumulation of pollutants (including heavy metals, pathogens and organic pollutants) in the soil. The behavior, mobility and bioavailability of heavy metals in soil are controlled by a number of complex physicochemical processes [101]. The mobility of metals can be greatly reduced in calcareous Mediterranean soils due to high soil $\mathrm{pH}$. Soil $\mathrm{pH}$ is a key variable in the redistribution of heavy metal distribution in biosolid-applied soils. In addition, low rainfall and high evapotranspiration can lead to metal accumulation in the first few centimeters of soil [102]. OM also plays an important role in the retention of heavy metals in the soil surface horizon [103]. The ability of soils to adsorb metal ions from aqueous solution is of particular interest and has implications for both agricultural issues such as soil fertility and environmental issues such as remediation of polluted soils and waste disposal [104]. The metal-soil interaction is such that when metals are introduced at the soil surface, their mobilization does not occur on a large scale unless the metal retention capacity of the soil is overloaded or metal interaction with the associated waste matrix enhances mobility.

\subsection{Legislation: National or/and Regional Requirements}

At the EU level, national laws have been created to implement EU directives and other related acts. Although information sources agree on the significant potential of biosolids recycling, one of the main barriers identified in biosolids land application is the lack of harmonization in the national regulatory framework. The legislation on sewage sludge, biosolids and their final use possibilities have been continuously changing and modifying. At the same time, management of growing quantities of sewage sludge collected on wastewater purification plants are becoming an acute issue of sustainability. In EU-28, about $50 \%$ of sewage sludge is spread on agricultural soils, and about $8 \%$ in Croatia [105]. However, there is a gap in reporting all the options in accommodating sewage sludge. Additionally, there are important divergences among the different regulations in Croatia, primarily regarding the permitted uses. For example, in 2016, disposal of sewage sludge in landfills for final disposal was prohibited [17]. Furthermore, in 2019, Ordinance on agricultural soil protection [106] put additional restrictions on agricultural use of biosolids, which calls for the control of legislative compliance. Therefore, the other governance instruments are needed for the clear division and delegation of responsibilities and competences in the administrative set-up for sludge management. Additionally, stakeholders should be provided with information on land potential before soliciting input on desired land use.

\section{Conclusions and Perspectives}

In this study, the potential of agricultural land in the coastal Adriatic Karst region (Šibenik region, Croatia) for biosolids application was evaluated by integrating spatial data from different sources: digital maps and remote sensing, parcel identification system, GIS field observations and measurements focusing on specific land, soil and biosolids properties.

Spatial analysis of the land resources identified only 6065 ha of 25,736 ha of agricultural land suitable for biosolids use. However, suitable land is divided into 26,288 parcels, dominantly occupied by olive orchards.

Furthermore, concentrations of certain heavy metals in soils in the Dinaric karst, in particular $\mathrm{Cd}, \mathrm{Cr}$ and $\mathrm{Ni}$, are inherently higher of the average for soils in general. Therefore, each load of material rich in heavy metals may lead to their accumulation in soil in concentrations that are harmful for the environment and humans.

$\mathrm{pH}$ is the key soil property that control the uptake of available elements into plants. High $\mathrm{pH}$ of soils in the study area, which is 7.89 in average, considerably reduces the bioavailability of potentially toxic elements. However, it is well known that the long-term 
application of biosolids produced from sewage sludge may decrease soil $\mathrm{pH}$, and thus enhance the uptake of toxic elements into plants.

Continuous increasing of the sewage sludge production imposes needs for diversification of sludge treatments and recycling methods. In case of the studied area, limited resources of land suitable for biosolids use were identified. Furthermore, the small and spatially scattered parcels considerably reduce the feasibility of biosolids land application.

Common international and national environmental standards for biosolids have largely been developed to date, but specific regional land features should certainly be considered. Basic criteria for assessing suitability are based on legislation, but each region must be carefully evaluated, taking into account specific characteristics not covered by legislation.

Comparatively small landscape units and catchments may seem marginal on a global scale in terms of impact on the aquatic environment. However, when dealing with the fractured karst geomorphology and aquifers, coastal floodplains and wetlands, and inland waters that rapidly communicate with seawater, such impacts quickly spread to the Adriatic Sea and beyond to the entire Mediterranean Sea. Therefore, regional studies limited to the specific and often small coastal regions, including islands, such as this one, can provide valuable input for the development of biosolids management systems on a regional scale.

The main challenges in biosolids land application in the Mediterranean karst region are related to the protection of the environment. Disposal on agricultural land was identified as a marginal option in this study, mainly due to the low availability of agricultural land and the small plots scattered throughout the karst area. Anyway, there are many other practical options, such as improving forest soil quality, reforestation and forest fires reclamations activities, maintenance of tourist areas and recreation zones, and many others. In any case, an assessment of both short-term and long-term impacts of biosolids amendment is recommended before their application to land in karst regions. In this study the spatial aspects of the problem were analyzed and to land suitable for biosolids application first was identified, while respecting the limits set by legislation.

The next recommendation is that the regional approaches in biosolids management in the Mediterranean karst region must be applied based on the uniqueness of landforms, hydro-geomorphology and climatic conditions, soil types and land use. Surface roughness, steep slopes and a complex fracture matrix system create complex pathways and velocities for solute migration. Selecting optimal activities for biosolids land application can reduce the risk of pollution distribution through heterogeneous groundwater flow.

Local and regional authorities should be provided with science-based information to identify the policies and methods for diversification of SS and biosolids management. The methodology for evaluating land potential for biosolids application combines data from different sources:

- qualitative and quantitative control of biosolids based on current legislation;

- $\quad$ environmental monitoring programs, mapping of land resources, land use and vulnerable areas, and the development of GIS-based models.

Ultimately, the results could help decision makers, managers of local wastewater treatment facilities, and landowners set realistic goals for efficient and sustainable application of biosolids on agricultural lands to ensure food security and land and water degradation neutrality in a fragile karst landscape.

Author Contributions: Conceptualization, V.H. and M.R.; validation, M.R., D.R., S.G.B. and M.Z.; investigation, V.H. and M.R.; resources, M.R., M.Č. and S.G.B.; data curation, H.B.B., V.H., M.R. and M.Č.; writing—original draft preparation, V.H. and M.R.; writing—review and editing, D.R., M.Z., H.B.B., M.Č., S.G.B. and M.R.; visualization, H.B.B. and M.Z.; supervision, M.R.; project administration, M.R. and H.B.B.; funding acquisition, M.R. and D.R. All authors have read and agreed to the published version of the manuscript.

Funding: This research was funded by Šibensko-kninska županija Program potpora poljoprivredi na području Šibensko-kninske županije za razdoblje 2016-2020., grant number 251-71-14-01/5-18-3 and 
by Croatian Science Foundation (HRZZ) and the Environmental Protection and Energy Efficiency Fund, Croatia, Program for encouraging research and development activities in the field of climate change, grant number HRZZ-PKP-2016-06-9041.

Institutional Review Board Statement: Not applicable.

Informed Consent Statement: Not applicable.

Data Availability Statement: Not applicable.

Acknowledgments: We thank Goran Andlar (University of Zagreb Faculty of Agriculture) for providing the photograph of Primošten (Croatia) dry stone walls site.

Conflicts of Interest: The authors declare no conflict of interest. The funders had no role in the design of the study; in the collection, analyses, or interpretation of data; in the writing of the manuscript, or in the decision to publish the results.

\section{References}

1. Cieślik, B.M.; Namieśnik, J.; Konieczka, P. Review of sewage sludge management: Standards, regulations and analytical methods. J. Clean. Prod. 2015, 90, 1-15. [CrossRef]

2. Fytili, D.; Zabaniotou, A. Utilization of sewage sludge in EU application of old and new methods-A review. Renew. Sustain. Energy Rev. 2008, 12, 116-140. [CrossRef]

3. EPA. Available online: https://www.epa.gov/biosolids/biosolids-laws-and-regulations (accessed on 24 May 2021).

4. Mei, X.; Tang, J.; Zhang, Y. Sludge stabilization: Characteristics of the end-products and an alternative evaluative methodology. Waste Manag. 2020, 105, 355-363. [CrossRef]

5. EC-Environment. Available online: https://ec.europa.eu/environment/topics/waste-and-recycling/sewage-sludge_hr (accessed on 24 May 2021).

6. Biosolids. Available online: https://www.epa.nsw.gov.au/your-environment/recycling-and-reuse/resource-recoveryframework/current-orders-and-exemption/resource-recovery-biosolids (accessed on 24 May 2021).

7. Sewage Sludge Directive 86/278. Available online: https: / ec.europa.eu/environment/topics/waste-and-recycling/sewagesludge_en (accessed on 24 May 2021).

8. WE. Available online: https://watereurope.eu/wp-content/uploads/WE-Position-Paper-on-the-Sewage-Sludge-Directive.pdf (accessed on 13 July 2021).

9. Gianico, A.; Braguglia, C.; Gallipoli, A.; Montecchio, D.; Mininni, G. Land Application of Biosolids in Europe: Possibilities, Con-Straints and Future Perspectives. Water 2021, 13, 103. [CrossRef]

10. Collivignarelli, M.; Abbà, A.; Frattarola, A.; Carnevale Miino, M.; Padovani, S.; Katsoyiannis, I.; Torretta, V. Legislation for the Reuse of Biosolids on Agricultural Land in Europe: Overview. Sustainancy 2019, 11, 6015. [CrossRef]

11. Oplanić, M.; Černe, M.; Palčić, I.; Major, N.; Ban, D. Study on the Possibilities for Using Sewage Sludge and Olive Pomace in Agriculture; Institute of Agriculture and Tourism: Poreč, Croatia, 2019. (In Croatian)

12. Legović, T.; Žutić, V.; Gržetić, Z.; Cauwet, G.; Precali, R.; Viličić, D. Eutrophication in the Krka estuary. Mar. Chem. 1994, 46, 203-215. [CrossRef]

13. Jakelić, K.; Romić, M.; Cukrov, N.; Bakić, H. Marine sediment geochemistry influenced by the treated city effluents discharge in the coastal zone of the Adriatic Sea (Šibenik, Croatia). In Book of Abstracts 31 st SEGH 2015, Proceedings of the International Conference of the Society for Environmental Geochemistry and Health, Bratislava, Slovak Republic, 22-26 June 2015; Fajcíková, K., Cvecková, V., Zvarová, I., Rapant, S., Eds.; State Geological Institute of Dionýz Štúr: Bratislava, Slovak Republic, 2015.

14. Kumar, V.; Chopra, A.K.; Kumar, A. A Review on Sewage Sludge (Biosolids) a Resource for Sustainable Agriculture. Arch. Agric. Environ. Sci. 2017, 2, 340-347. [CrossRef]

15. Mininni, G.; Blanch, A.R.; Lucena, F.; Berselli, S. EU policy on sewage sludge utilization and perspectives on new approaches of sludge management. Environ. Sci. Pollut. Res. 2015, 22, 7361-7374. [CrossRef] [PubMed]

16. Hudcová, H.; Vymazal, J.; Rozkošný, M. Present restrictions of sewage sludge application in agriculture within the European Union. Soil Water Res. 2019, 14, 104-120. [CrossRef]

17. Narodne Novine NN 38/08. Pravilnik o Gospodarenju Muljem Iz Uređaja Za Pročišćavanje Otpadnih Voda Kada Se Mulj Koristi U Poljoprivredi. Available online: https:/ / narodne-novine.nn.hr/clanci/sluzbeni/2008_04_38_1307.html (accessed on 24 May 2021).

18. Ford, D.; Williams, P. Karst Hydrogeology and Geomorphology; John Wiley \& Sons Ltd.: Chichester, UK, 2007; ISBN 9781118684986.

19. Burri, E.; Castiglioni, B.; Sauro, U. Agriculture, landscape and human impact in some karst areas of Italy. Int. J. Speleol. 1999, 28, 33-54. [CrossRef]

20. Romić, D.; Karoglan Kontić, J.; Preiner, D.; Romić, M.; Lazarević, B.; Maletić, E.; Ondrašek, G.; Andabaka, Ž.; Bakić Begić, H.; Bubalo Kovačić, M.; et al. Performance of grapevine grown on reclaimed Mediterranean karst land: Appearance and duration of high temperature events and effects of irrigation. Agric. Water Manag. 2020, 236, 106166. [CrossRef] 
21. Méndez, A.; Gómez, A.; Paz-Ferreiro, J.; Gascó, G. Effects of sewage sludge biochar on plant metal availability after application to a Mediterranean soil. Chemosphere 2012, 89, 1354-1359. [CrossRef]

22. Chagas, J.K.M.; de Figueiredo, C.C.; da Silva, J.; Paz-Ferreiro, J. The residual effect of sewage sludge biochar on soil availability and bioaccumulation of heavy metals: Evidence from a three-year field experiment. J. Environ. Manag. 2021, $279,111824$. [CrossRef]

23. Černe, M.; Palčić, I.; Pasković, I.; Major, N.; Romić, M.; Filipović, V.; Igrc, M.D.; Perčin, A.; Ban, S.G.; Zorko, B.; et al. The effect of stabilization on the utilization of municipal sewage sludge as a soil amendment. Waste Manag. 2019, 94, 27-38. [CrossRef]

24. Pérez-Gimeno, A.; Navarro-Pedreño, J.; Almendro-Candel, M.B.; Gómez, I.; Zorpas, A.A. The use of wastes (organic and inorganic) in land restoration in relation to their characteristics and cost. Waste Manag. Res. J. A Sustain. Circ. Econ. 2019, 37, 502-507. [CrossRef]

25. Jurun, E.; Ratković, N.; Ujević, I. A cluster analysis of Croatian counties as the base for an active demographic policy. Croat. Oper. Res. Rev. 2017, 8, 221-236. [CrossRef]

26. ARKOD. Available online: http:/ / preglednik.arkod.hr/ARKOD-Web/ (accessed on 24 May 2021).

27. ISO 11466:1995. Soil Quality_Extraction of Trace Elements Soluble in Aqua Regia; Croatian Standards Institute: Zagreb, Croatia, 2004.

28. Egner, H.; Riehm, H.; Domingo, W.R. Untersuchungen uber die chemische Bodenanalyse als Grundlage fur die Beurteilung des Nahrstoffzustandes der Boden, II: Chemische Extractionsmetoden zu Phosphorund Kaliumbestimmung. K. Lantbr. Annaler 1960, 26, 199-215.

29. Cunniff, P. Association of Official Analytical Chemists. Official Methods of Analysis of AOAC International, 16th ed.; AOAC: Arlington, VA, USA, 1995; Volume 1.

30. Bogunovic, M.; Vidacek, Z.; Racz, Z.; Husnjak, S.; Spoljar, A.; Sraka, M. Soil Map Croatia-Fao Unesco. Available online: https:/ / esdac.jrc.ec.europa.eu/content/soil-map-croatia-fao-unesco (accessed on 26 May 2021).

31. IUSS Working Group WRB. World Reference Base for Soil Resources 2014, Update 2015 International Soil Classification System for Naming Soils and Creating Legends for Soil Maps; World Soil Resources Reports No. 106.; FAO: Rome, Italy, 2015.

32. SAS Institute. SAS Procedures Guide for Personal Computers Version 9th Edition; SAS Institute: Cary North Carolina, SUA, 1999.

33. ESRI. ArcGIS Desktop: Release 10; Environmental Systems Research Institute: Redlands, CA, USA, 2011.

34. Romic, D.; Romic, M.; Zovko, M.; Bakic, H.; Ondrasek, G. Trace metals in the coastal soils developed from estuarine floodplain sediments in the Croatian Mediterranean region. Environ. Geochem. Health 2012, 34, 399-416. [CrossRef] [PubMed]

35. Romic, M.; Romic, D.; Dolanjski, D.; Stricevic, I. Heavy metals accumulation in topsoil from the winegrowing regions. Factors which Control retention. Agric. Conspec. Sci. 2004, 69, 1-10.

36. Halamić, J.; Miko, S. Geochemical Atlas of the Republic of Croatia; Croatian Geological Survey: Zagreb, Croatia, 2009.

37. Romić, M.; Matijević, L.; Bakić, H.; Romić, D. Copper Accumulation in Vineyard Soils: Distribution, Fractionation and Bioavailability Assessment. In Environmental Risk Assessment of Soil Contamination; Hernández-Soriano, M.C., Ed.; InTech: Rijeka, Croatia, 2014; pp. 799-825.

38. Husnjak, S.; Romić, M.; Poljak, M.; Pernar, N. Recommendations for Soil Management in Croatia. Agric. Conspec. Sci. Cus. 2011, $76,1-8$.

39. Romić, M.; Njavro, M.; Romić, D. Current and future challenges in agricultural land use and soil protection in Croatia. In Proceedings of the Central European Initiative on Agricultural Land Protection - CEILAND, Nitra, Slovak Republic, 2019; Lucia, P., Zuzana, L., Eds.; Slovak University of Agriculture in Nitra: Nitra, Slovak Republic, 2019; pp. 91-98.

40. Singh, R.P.; Agrawal, M. Potential benefits and risks of land application of sewage sludge. Waste Manag. 2008, 28, 347-358. [CrossRef]

41. Fuerhacker, M.; Haile, T.M. Treatment and reuse of sludge. In Waste Water Treatment and Reuse in the Mediterranean Region; Barceló, D., Petrovic, M., Eds.; Springer: Berlin/Heidelberg, Germany, 2011; pp. 63-92.

42. Islam, M.A.; Romić, D.; Akber, M.A.; Romić, M. Trace metals accumulation in soil irrigated with polluted water and assessment of human health risk from vegetable consumption in Bangladesh. Environ. Geochem. Health 2018, 40, 59-85. [CrossRef]

43. Eggen, R.I.L.; Hollender, J.; Joss, A.; Schärer, M.; Stamm, C. Reducing the Discharge of Micropollutants in the Aquatic Environment: The Benefits of Upgrading Wastewater Treatment Plants. Environ. Sci. Technol. 2014, 48, 7683-7689. [CrossRef] [PubMed]

44. Corradini, F.; Meza, P.; Eguiluz, R.; Casado, F.; Huerta-Lwanga, E.; Geissen, V. Evidence of microplastic accumulation in agricultural soils from sewage sludge disposal. Sci. Total. Environ. 2019, 671, 411-419. [CrossRef] [PubMed]

45. Randazzo, W.; Truchado, P.; Cuevas-Ferrando, E.; Simón, P.; Allende, A.; Sánchez, G. SARS-CoV-2 RNA in wastewater anticipated COVID-19 occurrence in a low prevalence area. Water Res. 2020, 181, 115942. [CrossRef]

46. Roberta, M.H. Agriculture, Forestry And Fishery Statistics; Eurostat: Luxembourg, 2015; ISBN 9789279432026.

47. Tran, N.H.; Reinhard, M.; Gin, K.Y.-H. Occurrence and fate of emerging contaminants in municipal wastewater treatment plants from different geographical regions-a review. Water Res. 2018, 133, 182-207. [CrossRef] [PubMed]

48. Gilli, E. Karstology: Karsts, Caves And Springs; CRC Press: New York, NY, USA, 2015.

49. de Brogniez, D.; Ballabio, C.; Stevens, A.; Jones, R.J.A.; Montanarella, L.; van Wesemael, B. A map of the topsoil organic carbon content of Europe generated by a generalized additive model. Eur. J. Soil Sci. 2015, 66, 121-134. [CrossRef]

50. EC-EIP. Available online: https://ec.europa.eu/eip/agriculture/sites/default/files/eipagri_fg_soil_organic_matter_final_ report_2015_en_0.pdf (accessed on 13 June 2021). 
51. Panagos, P.; Borrelli, P.; Poesen, J.; Ballabio, C.; Lugato, E.; Meusburger, K.; Montanarella, L.; Alewell, C. The new assessment of soil loss by water erosion in Europe. Environ. Sci. Policy 2015, 54, 438-447. [CrossRef]

52. Gutierrez, F.; Kinney, K.A.; Katz, L.E. Phosphorus Speciation in Municipal Wastewater Solids and Implications for Phosphorus Recovery. Environ. Eng. Sci. 2020, 37, 316-327. [CrossRef]

53. Antoniadis, V.; Koutroubas, S.D.; Fotiadis, S. Nitrogen, Phosphorus, and Potassium Availability in Manure-and Sewage Sludge-Applied Soil. Commun. Soil Sci. Plant Anal. 2015, 46, 393-404. [CrossRef]

54. Bramryd, T. Impact of sewage sludge application on the long-term nutrient balance in acid soils of scots pine (Pinus sylvestris L.) forests. Water Air Soil Pollut. 2002, 140, 381-399. [CrossRef]

55. Zhang, Z.; Lv, Y.; Zhang, W.; Zhang, Y.; Sun, C.; Marhaba, T. Phosphorus, organic matter and nitrogen distribution characteristics of the surface sediments in Nansi Lake, China. Environ. Earth Sci. 2015, 73, 5669-5675. [CrossRef]

56. Casado-Vela, J.; Sellés, S.; Navarro, J.; Bustamante, M.A.; Mataix, J.; Guerrero, C.; Gomez, I. Evaluation of composted sewage sludge as nutritional source for horticultural soils. Waste Manag. 2006, 26, 946-952. [CrossRef]

57. Korboulewsky, N.; Dupouyet, S.; Bonin, G. Environmental Risks of Applying Sewage Sludge Compost to Vineyards. J. Environ. Qual. 2002, 31, 1522-1527. [CrossRef]

58. Khan, S.; Chao, C.; Waqas, M.; Arp, H.P.H.; Zhu, Y.-G. Sewage Sludge Biochar Influence upon Rice (Oryza sativa L) Yield, Metal Bioaccumulation and Greenhouse Gas Emissions from Acidic Paddy Soil. Environ. Sci. Technol. 2013, 47, 8624-8632. [CrossRef]

59. Kidd, P.S.; Domínguez-Rodríguez, M.J.; Díez, J.; Monterroso, C. Bioavailability and plant accumulation of heavy metals and phosphorus in agricultural soils amended by long-term application of sewage sludge. Chemosphere 2007, 66, 1458-1467. [CrossRef] [PubMed]

60. McDowell, R.W.; Sharpley, A.N. Approximating Phosphorus Release from Soils to Surface Runoff and Subsurface Drainage. J. Environ. Qual. 2001, 30, 508-520. [CrossRef] [PubMed]

61. Filipović, V.; Černe, M.; Šimůnek, J.; Filipović, L.; Romić, M.; Ondrašek, G.; Bogunović, I.; Mustać, I.; Krevh, V.; Ferenčević, A.; et al. Modeling Water Flow and Phosphorus Sorption in a Soil Amended with Sewage Sludge and Olive Pomace as Compost or Biochar. Agronomy 2020, 10, 1163. [CrossRef]

62. Miah, M.Y.; Chiu, C.-Y.; Hayashi, H.; Chino, M. Barley growth in response to potassium fertilization of soil with long term application of sewage sludge. Soil Sci. Plant Nutr. 1999, 45, 499-504. [CrossRef]

63. Junio, G.R.Z.; Sampaio, R.A.; Nascimento, A.L.; Carneiro, J.P.; Santos, L.D.T.; Fernandes, L.A. Corn yield response to residual effect of fertilization with sewage sludge compost and rock phosphate. Braz J Agric Env. 2013, 17, 706-712.

64. Perez-Murcia, M.D.; Moral, R.; Moreno-Caselles, J.; Perez-Espinosa, A.; Paredes, C. Use of composted sewage sludge in growth media for broccoli. Bioresour. Technol. 2006, 97, 123-130. [CrossRef]

65. Casado-Vela, J.; Sellés, S.; Díaz-Crespo, C.; Navarro-Pedreño, J.; Mataix-Beneyto, J.; Gómez, I. Effect of composted sewage sludge application to soil on sweet pepper crop (Capsicum annuum var. annuum) grown under two exploitation regimes. Waste Manag. 2007, 27, 1509-1518. [CrossRef] [PubMed]

66. Sousa, A.A.T.C.; Figueiredo, C.C. Sewage sludge biochar: Effects on soil fertility and growth of radish. Biol. Agric. Hortic. 2016, 32, 127-138. [CrossRef]

67. SWIM-H2020 SM-Sustainable Water Integrated Management and Horizon 2020 Support Mechanism. LDK Consultants Engineers \& Planners SA. Available online: https: / / www.euneighbours.eu/en/south/stay-informed/projects/swim-h2020-smsustainable-water-integrated-management-and-horizon-2020 (accessed on 10 June 2021).

68. Škorić, A.; Filipovski, G.; Ćirić, M. Klasifikacija zemljišta Jugoslavije; Posebna izdanja ANU BiH, knjiga LXXVII, Odjeljenje priodnih i matematiĉkih nauka; Akademija nauka i umjetnosti Bosne i Hercegovine: Sarajevo, Bosnia and Herzegovina, 1985.

69. Miko, S.; Halamić, J.; Peh, Z.; Galović, L. Geochemical Baseline Mapping of Soils Developed on Diverse Bedrock from Two Regions in Croatia. Geol.Croat. 2001, 54, 53-118. [CrossRef]

70. Urlić, B.; Dumičić, G.; Goreta Ban, S.; Romić, M. Mineral composition of kale genotypes grown in three soils. Acta Hortic. 2016, 1142, 247-252. [CrossRef]

71. Xia, X.; Ji, J.; Yang, Z.; Han, H.; Huang, C.; Li, Y.; Zhang, W. Cadmium risk in the soil-plant system caused by weathering of carbonate bedrock. Chemosphere 2020, 254, 126799. [CrossRef] [PubMed]

72. Miloš, B.; Bensa, A. Background Variation and Threshold Values for Cadmium Concentration in Terra Rossa Soil from Dalmatia, Croatia. Eurasian Soil Sc. 2019, 52, 1622-1631. [CrossRef]

73. Quezada-Hinojosa, R.P.; Föllmi, K.B.; Verrecchia, E.; Adatte, T.; Matera, V. Speciation and multivariable analyses of geogenic cadmium in soils at Le Gurnigel, Swiss Jura Mountains. Catena 2015, 125, 10-32. [CrossRef]

74. Fang, W.; Delapp, R.C.; Kosson, D.S.; van der Sloot, H.A.; Liu, J. Release of heavy metals during long-term land application of sewage sludge compost: Percolation leaching tests with repeated additions of compost. Chemosphere 2017, 169, 271-280. [CrossRef]

75. Filipović, L.; Romić, M.; Romić, D.; Filipović, V.; Ondrašek, G. Organic matter and salinity modify cadmium soil (phyto)availability. Ecotoxicol. Environ. Saf. 2018, 147, 824-831. [CrossRef]

76. Ščančar, J.; Milačič, R.; Stražar, M.; Burica, O. Total metal concentrations and partitioning of $\mathrm{Cd}, \mathrm{Cr}, \mathrm{Cu}, \mathrm{Fe}, \mathrm{Ni}$ and $\mathrm{Zn}$ in sewage sludge. Sci. Total. Environ. 2000, 250, 9-19. [CrossRef] 
77. Fang, W.; Qi, G.; Wei, Y.; Kosson, D.S.; van der Sloot, H.A.; Liu, J. Leaching characteristic of toxic trace elements in soils amended by sewage sludge compost: A comparison of field and labora-tory investigations. Environ. Pollut 2018, 237, 244-252. [CrossRef] [PubMed]

78. Liu, H.; Guo, X. Hydroxyapatite reduces potential Cadmium risk by amendment of sludge compost to turf-grass grown soil in a consecutive two-year study. Sci. Total Environ. 2019, 661, 48-54. [CrossRef] [PubMed]

79. Ghallab, A.; Usman, A.R.A. Effect of Sodium Chloride-induced Salinity on Phyto-availability and Speciation of Cd in Soil Solution. Water. Air. Soil Pollut. 2007, 185, 43-51. [CrossRef]

80. Perez-Espinosa, A.; Moreno-Caselles, J.; Moral, R.; Perez-Murcia, M.D.; Gomez, I. Effects of sewage sludge application on salinity and physico-chemical properties of a calcareous soil. Arch. Agron. Soil Sci. 2000, 45, 51-56. [CrossRef]

81. Hanc, A.; Tlustos, P.; Szakova, J.; Habart, J. Changes in cadmium mobility during composting and after soil application. Waste Manag. 2009, 29, 2282-2288. [CrossRef]

82. Qi, G.; Jia, Y.; Liu, W.; Wei, Y.; Du, B.; Fang, W.; Guo, Y.; Guo, F.; Wu, Y.; Zou, Q.; et al. Leaching behavior and potential ecological risk of heavy metals in Southwestern China soils applied with sewage sludge compost under acid precipitation based on lysimeter trials. Chemosphere 2020, 249, 126212. [CrossRef]

83. Milačič, R.; Ščančar, J. Determination of hexavalent chromium in lime-treated sewage sludge by anion-exchange fast protein liquid chromatography with electrothermal atomic absorption spectrometry detection. Analyst 2000, 125, 1938-1942. [CrossRef]

84. Černe, M.; Palčić, I.; Major, N.; Pasković, I.; Perković, J.; Užila, Z.; Filipović, V.; Romić, M.; Goreta Ban, S.; Jaćimović, R.; et al Effect of sewage sludge derived compost or biochar amendment on the phytoaccumulation of potentially toxic elements and radionuclides by Chinese cabbage. J. Environ. Manage 2021, 293, 112955. [CrossRef]

85. Martínez, C.E.; Motto, H.L. Solubility of lead, zinc and copper added to mineral soils. Environ. Pollut. 2000, 107, 153-158. [CrossRef]

86. Torri, S.I.; Lavado, R.S. Dynamics of $\mathrm{Cd}, \mathrm{Cu}$ and $\mathrm{Pb}$ added to soil through different kinds of sewage sludge. Waste Manag. 2008, 28, 821-832. [CrossRef]

87. Lucchini, P.; Quilliam, R.S.; DeLuca, T.H.; Vamerali, T.; Jones, D.L. Does biochar application alter heavy metal dynamics in agricultural soil? Agric. Ecosyst. Environ. 2014, 184, 149-157. [CrossRef]

88. Filipović, J.; Grčić, I.; Bermanec, V.; Kniewald, G. Monitoring of total metal concentration in sludge samples: Case study for the mechanical-biological wastewater treatment plant in Velika Gorica, Croatia. Sci. Total. Environ. 2013, 447, 17-24. [CrossRef]

89. Sčančar, J.; Milačić, R.; Burica, O.; Stražar, M. Water and acetic acid leachable $\mathrm{Cd}, \mathrm{Cr}, \mathrm{Cu}, \mathrm{Fe}, \mathrm{Ni}, \mathrm{Pb}$ and $\mathrm{Zn}$ in lime-treated sewage sludge. Ann. Chim. 2001, 9, 375-379.

90. Zheljazkov, V.D.; Warman, P.R. Phytoavailability and fractionation of copper, manganese, and zinc in soil following application of two composts to four crops. Environ. Pollut. 2004, 131, 187-195. [CrossRef] [PubMed]

91. Wei, Y.; Liu, Y. Effects of sewage sludge compost application on crops and cropland in a 3-year field study. Chemosphere 2005, 59, 1257-1265. [CrossRef] [PubMed]

92. Sterrett, S.B.; Chaney, R.L.; Gifford, C.H.; Mielke, H.W. Influence of fertilizer and sewage sludge compost on yield and heavy metal accumulation by lettuce grown in urban soils. Environ. Geochem. Health 1996, 18, 135-142. [CrossRef]

93. Khanmohammadi, Z.; Afyuni, M.; Mosaddeghi, M.R. Effect of sewage sludge and its biochar on chemical properties of two calcareous soils and maize shoot yield. Arch. Agron. Soil Sci. 2017, 63, 198-212. [CrossRef]

94. Yue, Y.; Cui, L.; Lin, Q.; Li, G.; Zhao, X. Efficiency of sewage sludge biochar in improving urban soil properties and promoting grass growth. Chemosphere 2017, 173, 551-556. [CrossRef]

95. Boumaiza, L.; Chesnaux, R.; Drias, T.; Walter, J.; Huneau, F.; Garel, E.; Knoeller, K.; Stumpp, C. Identifying groundwater degradation sources in a Mediterranean coastal area experiencing significant multi-origin stresses. Sci. Total. Environ. 2020, 746, 141203. [CrossRef]

96. Kralj, D.; Romic, D.; Romic, M.; Cukrov, N.; Mlakar, M.; Kontrec, J.; Barisic, D.; Sirac, S. Geochemistry of stream sediments within the reclaimed coastal floodplain as indicator of anthropogenic impact (River Neretva, Croatia). J. Soils Sediments 2016, 16, 1150-1167. [CrossRef]

97. Felja, I.; Romić, M.; Romić, D.; Bakić, H.; Pikelj, K.; Juračić, M. Application of empirical model to predict background metal concentration in mixed carbonate-alumosilicate sediment (Adriatic Sea, Croatia). Mar. Pollut. Bull. 2016, 106, 190-199. [CrossRef] [PubMed]

98. Romić, D.; Castrignanò, A.; Romić, M.; Buttafuoco, G.; Bubalo Kovačić, M.; Ondrašek, G.; Zovko, M. Modelling spatial and temporal variability of water quality from different monitoring stations using mixed effects model theory. Sci. Total. Environ. 2020, 704, 135875. [CrossRef]

99. Petitta, M.; Tallini, M. Groundwater Resources and Human Impacts in a Quaternary Intramontane Basin (L'Aquila Plain, Central Italy). Water Int. 2003, 28, 57-69. [CrossRef]

100. Dinelli, E.; Cortecci, G.; Lucchini, F.; Zantedeschi, E. Sources of major and trace elements in the stream sediments of the Arno river catchment (northern Tuscany, Italy). Geochem. J. 2005, 39, 531-545. [CrossRef]

101. Lu, Q.; He, Z.L.; Stoffella, P.J. Land Application of Biosolids in the USA: A Review. Appl. Environ. Soil Sci. 2012, $2012,256-263$. [CrossRef]

102. Zovko, M.; Romic, M. Soil contamination by trace metals: Geochemical behaviour as an element of risk assessment. In Earth and Environmental Sciences; Dar, I.A., Ed.; InTech: Rijeka, Croatia, 2011; pp. 437-456. 
103. Romic, M.; Bragato, G.; Zovko, M.; Romic, D.; Mosetti, D.; Galovic, L.; Bakic, H. The characteristics of cultivated soils developed from coastal paleosand (Korcula Island, Croatia). CATENA 2014, 113, 281-291. [CrossRef]

104. Bradl, H.B. Adsorption of heavy metal ions on soils and soils constituents. J. Colloid Interface Sci. 2004, 277, 1-18. [CrossRef]

105. EC_Eurostat. Available online: https://ec.europa.eu/eurostat/databrowser/view/ENV_WW_SPD/default/table?lang=en (accessed on 10 June 2021).

106. Narodne Novine NN 71/19. Pravilnik o Zaštiti Poljoprivrednog Zemljišta od Onečišćenja. Available online: https:/ / narodnenovine.nn.hr/clanci/sluzbeni/2019_07_71_1507.html (accessed on 24 May 2021). 